\title{
Beneficios tributarios otorgados por las entidades territoriales en el marco del principio de autonomía territorial
}

\author{
Tax Benefits given by Territorial \\ Institutions, following a Territorial \\ Autonomy Principle
}

Benefícios fiscais concedidos por entidades territoriais sob o princípio de autonomia territorial

Juan Camilo Cardona Buitrago*

Abogado, Contador Público y Especialista en Legislación tributaria de la Universidad Católica de Oriente. Magister en Derecho del Estado con énfasis en Derecho Tributario de la Universidad Externado de Colombia. Correo-e: jccardona@uco.edu.co. oRDCID: https://orcid.org/0000-0002-2308-1427 Dor: https://doi.org/10.18601/16926722.n17.09 


\title{
Resumen
}

Los beneficios tributarios otorgados por las entidades territoriales en el marco de la autonomía territorial son considerados como instrumentos para incentivar el desarrollo económico y social de las jurisdicciones. Los municipios, según preceptos constitucionales, se consideran como entidades descentralizadas; en efecto, tienen la facultad para administrar y gestionar sus propios recursos.

En consideración del artículo 38 de la Ley 14 de 1983, el establecimiento de los beneficios tributarios por parte de las entidades territoriales estará limitada por el término de diez años; tiempo en el cual un ente territorial podrá otorgar exenciones.

La vocación industrial del Valle de San Nicolás ha posibilitado la transformación del territorio, generando cambios significativos en la estructura productiva de la región; posicionándose de esta manera como atractiva para el asentamiento empresarial y, en efecto, propiciando la competencia fiscal entre jurisdicciones para atraer contribuyentes a través de tratamientos preferenciales.

En consecuencia, en el presente artículo se efectúa el análisis de la estructura jurídica de las exenciones otorgadas por los municipios de Guarne y Rionegro, en el Valle de San Nicolás, oriente antioqueño; el asentamiento empresarial y sus efectos en el recaudo; el mercado laboral y su comportamiento para las vigencias comprendidas entre los años 2008 y 2017.

Palabras clave: Autonomía territorial; Beneficios tributarios; Sistema tributario; Impuesto.

\begin{abstract}
Tax benefits given by territorial institutions, following a territorial autonomy principle, are considered as tools for social and economic development in the jurisdictions. Municipalities, according to constitution principles, are considered as decentralized entities; in fact, they have the faculty to manage and take care of their own resources.
\end{abstract}

Considering article 38 on Law 14 of 1983, establishing of tax benefits will be limited by a ten years term; this is the time while a territorial entity will be able to give this possibility.

Industrial tendency at San Nicolas Valley, have made the possibility for a territory transformation, generating big changes in region's productive structure; situating itself as an atractive possibility for enterprise location and of course making possible tax 
competences between jurisdictions in order to attract contributors because of preferential treatments.

According to this, the present article is an analysis of legal structure about benefits given by municipalities of Rionegro and Guarne in San Nicolas Valley, Eastern Antioquia, Enterprise location and its effects on tax collection, labor market and its behavior for the next validity included from 2008 until 2017.

Keywords: Territorial autonomy; Tax Benefits; Tax System; Tax.

\section{Resumo}

Os benefícios fiscais concedidos por entidades territoriais no âmbito da autonomia territorial são considerados instrumentos para incentivar o desenvolvimento econômico e social das jurisdições. Os municípios, de acordo com os requisitos constitucionais, são considerados entidades descentralizadas; de fato, eles têm o poder de administrar e gerenciar seus próprios recursos.

Em consideração ao artigo 38 da lei 14 de 1983; o estabelecimento de benefícios físcais por entidades territoriais será limitado pelo prazo de dez anos; período em que uma entidade territorial pode conceder isenções.

A vocação industrial do vale de San Nicolás possibilitou a transformação do território, gerando mudanças significativas na estrutura produtiva da região; posicionando-se assim como atraente para a liquidação de negócios e, com efeito, promovendo a concorrência tributária entre jurisdições para atrair contribuintes por meio de tratamentos preferenciais.

Consequentemente, este artigo analisa a estrutura legal das isenções concedidas pelos municípios de Guarne e Rionegro no vale de San Nicolás, leste da Antioquia, estabelecimento de negócios e seus efeitos na coleta, mercado de trabalho e seu comportamento para as validades entre os anos de 2008 e 2017.

Palavras chave: Autonomia territorial; Benefícios fiscais; Sistema tributário; Imposto.

\section{Introducción}

Los beneficios tributarios otorgados por las entidades territoriales en el marco del principio de autonomía territorial son considerados como instrumentos para incentivar el desarrollo económico y social de las jurisdicciones. Los municipios, según preceptos 
constitucionales, son considerados como entidades descentralizadas; en efecto, tienen la facultad para administrar y gestionar sus propios recursos.

En consideración al artículo 38 de la Ley 14 de 1983, el establecimiento de los beneficios tributarios por parte de las entidades territoriales estará limitada por el termino de diez años; tiempo en el cual un ente territorial podrá otorgar exenciones; en efecto, la entidad territorial deberá establecer los requisitos para acceder a los beneficios y condicionar el tratamiento preferencial al periodo de tiempo establecido en el acuerdo municipal.

La vocación industrial del Valle de San Nicolás ha posibilitado la transformación del territorio, generando cambios significativos en la estructura productiva de la región; posicionándose de esta manera como atractiva para el asentamiento empresarial; propiciando de esta forma la competencia fiscal entre jurisdicciones para atraer contribuyentes a través de tratamientos preferenciales. En consecuencia, en el presente artículo se efectúa el análisis de la estructura jurídica de las exenciones otorgadas por los municipios de Rionegro y Guarne en el Valle de San Nicolás, oriente antioqueño, el asentamiento empresarial, los efectos en el mercado laboral y su comportamiento para las vigencias comprendidas entre los años 2008 y 2017.

De tal forma, se analizan los efectos del asentamiento empresarial en los municipios de Rionegro y Guarne, en consideración a las discusiones que se pueden dar alrededor de los beneficios tributarios en materia del Impuesto de Industria y Comercio; para cumplir la finalidad señalada, se llevará a cabo una revisión teórica de la normatividad, jurisprudencia y doctrina relacionada con el objeto de estudio, con el fin de conocer el estado del arte de la cuestión, y obtener los insumos básicos necesarios para decantar el abordaje metodológico.

Con base en lo mencionado, el presente artículo se enmarca en un estudio apoyado en el Derecho económico a partir de los efectos económicos generados como consecuencia de la aplicación de las disposiciones normativas; en efecto, el objetivo general del presente artículo consiste en analizar los beneficios tributarios otorgados por las entidades territoriales en el marco del principio de autonomía territorial, para lo cual se necesita cumplir los siguientes objetivos específicos: dar cuenta del poder tributario de la entidades territoriales en relación con los beneficios fiscales en tributos de su propiedad o que estén bajo su administración; así mismo, revisar las clases de beneficios tributarios existentes aplicables al Impuesto de Industria y Comercio en los municipios de Rionegro y Guarne, $\mathrm{y}$, finalmente, evaluar la incidencia de los beneficios tributarios en el recaudo tributario y el asentamiento empresarial en la generación de nuevos empleos como consecuencia de la concesión de tratamientos preferenciales en el ICA.

Para lograr dichos objetivos, la estructura empleada en el artículo consta de 3 acápites y finaliza con las conclusiones. En el primer acápite, se describe la incidencia de la descentralización en el ejercicio de la autonomía territorial por parte de las entidades territoriales, la soberanía fiscal en la gestión de sus propios intereses, y el marco normativo que regula el Impuesto de Industria y Comercio en Colombia, así mismo se da cuenta de su regulación jurídica y fallos jurisprudenciales que se han suscitado en relación con el objeto 
de estudio; lo anterior, con el fin de entregar un estado del arte al lector sobre el objeto de estudio, que a su vez fijará ciertas pautas para su compresión posterior.

En el segundo acápite, con el fin de ubicar al lector, se realiza un estudio de la posición geográfica y económica de los municipios objeto de estudio. De tal modo, se iniciará el segundo acápite con el análisis de la estructura jurídica de las exenciones otorgadas por los municipios del Rionegro y Guarne, en el Valle de San Nicolás, el asentamiento industrial y sus efectos en el mercado laboral, mostrando de manera ejemplificativa el contenido de los acuerdos que reglamentan beneficios tributarios otorgados por los municipios objeto de estudio para incentivar el asentamiento empresarial en el periodo 2008-2017; en consecuencia, se efectúa el análisis de la información reportada por los suscitados municipios en el Consolidador de Hacienda e Información Pública -CHIP- a efectos de evaluar el comportamiento de los ingresos por concepto de industria y comercio.

En el tercer acápite se efectúa el análisis de la incidencia de la autonomía territorial en la concesión de exenciones que posibilitan el asentamiento empresarial en los municipios de Guarne y Rionegro, así como los efectos en la generación de empleo.

Finalmente, se extraen las conclusiones que fue posible obtener de la investigación, denotando las problemáticas que se suscitan con la aplicación de este tipo de instrumentos de política fiscal, cuestionando si este tipo de medidas jurídicas tienen efectos económicos para la entidad territorial en el recaudo y la obtención de beneficios extrafiscales.

El poder tributario de las entidades territoriales. Aplicabilidad a los beneficios tributarios en el Impuesto de Industria y Comercio.

En este acápite se expondrá la incidencia de la descentralización en el ejercicio de la autonomía territorial por parte de las entidades territoriales; la soberanía fiscal en la gestión de sus propios intereses, y se evidenciará el marco normativo que regula el Impuesto de Industria y Comercio en Colombia; así mismo, se hará una aproximación conceptual al concepto de beneficio fiscal a partir de los antecedentes jurisprudenciales, doctrinales y su aplicabilidad por parte de las entidades territoriales en el marco de la autonomía territorial.

\section{A. Descentralización y autonomía territorial como principio constitucional}

El proceso de descentralización de las entidades territoriales en Colombia ha demarcado el punto de partida para la materialización del Estado en forma de república unitaria con autonomía de sus entidades territoriales; en este sentido, la Constitución Política de Colombia, en su artículo 1, dispone: "Colombia es un Estado Social de Derecho, organizado en forma de República unitaria, descentralizada, con autonomía de sus entidades territoriales, democrática, participativa y pluralista, fundada en el respeto de la dignidad humana, en el trabajo y la solidaridad de las personas que la integran y en la prevalencia del interés general" (destacado fuera del original).

De tal forma, los gobiernos locales iniciaron un proceso de regionalización, caracterizado por la atribución de competencias y administración de recursos que implicaría el aumento de las responsabilidades de las entidades territoriales. 
En consideración a lo anterior, Rodríguez (2013) define la descentralización territorial como:

El otorgamiento de competencias o funciones administrativas a las colectividades regionales o locales, para que las ejerzan a su propio nombre y bajo su propia responsabilidad. Es decir, que se le otorga a las colectividades locales cierta autonomía para que las manejen por sí mismas. En Colombia, esta descentralización se manifiesta en la existencia de los departamentos, los distritos y los municipios que, por lo mismo, reciben el nombre de entidades territoriales (...).

En consecuencia, la descentralización tiene por una parte un fundamento de conveniencia, en el sentido de que se considera que es favorable para las diversas comunidades tener capacidad para resolver sus propios asuntos y no que ellos les sean resueltos directamente por el Estado.

Por otra parte, tiene también un fundamento político, en cuanto se dice que es una manifestación de la democracia en la medida que permite a las comunidades su autogobierno (Rodríguez, 2013).

En este sentido, el autor considera que la descentralización debe ser entendida como un fenómeno jurídico que permite a las entidades territoriales deprenderse de algunas de las funciones públicas del Estado central.

Por su parte, Alfonso (2015) efectúa una clasificación doctrinal de la descentralización en los siguientes términos:

La descentralización se presenta en tres modalidades: (i) territorial, que se expresa en las entidades territoriales y permite la configuración de los órdenes del Estado(nacional y territorial) (C.P. artículo 1); (ii) por servicios ${ }^{10}$, que da lugar a las entidades descentralizadas y constituye la base de los sectores administrativos, sector central y sector descentralizado, en cada uno de los órdenes del Estado (C.P. artículo 209); y (iii) por colaboración ${ }^{11}$, en la cual particulares, autorizados legalmente, ejercen funciones públicas, verbi gracia, las cámaras de comercio (p. 7).

En este orden de ideas, el proceso de descentralización ha conllevado que las entidades territoriales tengan una misma organización política, administrativa y financiera sometida a un mismo ordenamiento jurídico que encuentra su génesis en el primer inciso del artículo 1 de la Constitución Política de $1991^{[1]}$. En efecto, las competencias reconocidas a las entidades territoriales en el marco de la autonomía territorial redefinen las funciones de los diferentes niveles del ente central, materializando de esta manera los poderes jurídicos para gestionar sus propios intereses; aumentando las responsabilidades

1 Colombia es un Estado Social de Derecho, organizado en forma de República unitaria, descentralizada, con autonomía de sus entidades territoriales. 
de los departamentos, distritos y municipios; no obstante, la descentralización en Colombia ha traído para las entidades territoriales limitaciones de carácter económico y administrativo.

En consideración a la suscitada interrelación entre el fenómeno de la descentralización y la autonomía territorial, Penagos (2013) señala lo siguiente:

Bien estudiada la descentralización territorial en el Estado unitario colombiano, se colige sin mayor esfuerzo que nuestro sistema no es totalmente descentralizado, sino desconcentrado, por cuanto existen exageradas limitaciones competenciales de carácter administrativo y económico, además de la orientación, control y evaluación general de actividades de los organismos y entidades administrativas que ejerce el Presidente de la República, los ministros, los directores de los departamentos administrativos, los superintendentes, los gobernadores, los alcaldes y los representantes legales de las entidades descentralizadas y las sociedades de economía mixta de cualquier nivel administrativo (p 14).

En concordancia con lo anterior, la descentralización ha tenido como fin otorgar a las entidades territoriales una denominada soberanía fiscal limitada, autonomía territorial, en consideración a la gestión y administración de los recursos de su propiedad.

No obstante, en la Sentencia C-517 de 1992 se precisa el contenido constitucional básico de los elementos integrantes de la autonomía territorial:

1) El derecho de las entidades territoriales a gobernarse por autoridades propias, elegidas y constituidas democráticamente; 2) el derecho de cada entidad territorial a ejercer libremente las competencias constitucionales y legales que le correspondan; 3) el derecho a participar en las rentas nacionales, tal como lo señala la Constitución, y 4) el derecho de los entes territoriales a administrar sus recursos propios y a establecer los tributos necesarios para el cumplimiento de sus funciones.

Pues bien, el desarrollo jurisprudencial de la Corte Constitucional en torno al principio de autonomía territorial encuentra sustento en la Sentencia C-517 de 1992, en la que señala:

hace(n) referencia a un cierto grado de libertad en la toma de decisiones por parte de un determinado ente jurídico en relación con otro.

En este sentido, Buitrago (2016) comenta que la Corte Constitucional ha considerado la inexistencia de soberanía fiscal de los departamentos y municipios, considerando: a) Que Colombia es un Estado unitario, b) que el ejercicio de la autonomía de las entidades territoriales está sujeto a la Constitución y la ley, c) que las entidades territoriales dentro de su 
autonomía, pueden establecer contribuciones pero siempre y cuando respeten los marcos establecidos por la ley².

No obstante, el profesor Lewin Figueroa, citado por Bernal (2005), esboza la postura de la Corte Constitucional frente a la autonomía tributaria, haciendo alusión a la Sentencia C-517 de 1992, en la que

(...) la Corte juzga necesario poner de presente que la denominada tesis de la soberanía fiscal de las entidades territoriales no tiene asidero constitucional. Así se infiere de manera clara e inequívoca no solo del contexto sistemático de la carta y en particular de los artículos citados, sino además de la misma historia de dicha iniciativa. La propuesta de consagrarla fue derrotada en la Asamblea Constitucional. Esos mismos elementos permiten sin reticencias afirmar que en la nueva carta el constituyente en esta materia conservo los lineamientos básicos del régimen anterior pues les reconoció una autonomía fiscal limitada. Es decir, su ejercicio se subordina a los términos que señale la Ley (Sentencia C-517 de 1992).

Pues bien, la posición reflejada por la Corte, desde el mismo inicio de su función como suprema guardadora de la Constitución, es la de considerar que no existe una total autonomía fiscal en cabeza de las entidades territoriales. Esta tesis se ha mantenido durante toda la evolución jurisprudencial constitucional, como se ve en Sentencia C-335 de 1996, citada por el doctor Lewin.

Adicionalmente, la Corte Constitucional en Sentencia C-506 de 1995, manifestó al respecto: “'Estado Social de Derecho', 'democracia participativa' y 'autonomía territorial' no son más que expresiones de un único fin: el desarrollo integral del hombre dentro de su contexto social".

A su vez, el doctor Lewin comenta: "la autonomía y la descentralización, reconocidas a las entidades territoriales, no deben ser entendidas en términos absolutos, pues esto llevaría a una incompleta interpretación de aquellos conceptos, lo cual implica una escisión del sistema de principios, garantizado por la Constitución”.

En este mismo sentido, Rodríguez (2014) refiere la consolidación de la autonomía territorial en la Sentencia C-127 de 2002, así:

(La) territorialidad y (la) unidad nacional (son) dos elementos teleológicamente inescindibles, ontológicamente diferenciables a partir de su materialidad geográfica, con unos destinatarios comunes -los habitantes del país-, y por entero, instancias orgánicas y funcionales de un mismo mecanismo estatal: el de la República unitaria, descentralizada, con autonomía de sus entidades territoriales, democrática, participativa y pluralista (Sentencia C-127 de 2002). 
En este orden de ideas, el citado autor señala que, en tal virtud, el límite mínimo de la autonomía territorial garantizado por la Constitución constituye su núcleo esencial y está integrado por el conjunto de derechos, atribuciones y facultades reconocidas en la Carta Política a las entidades territoriales y a sus autoridades, para el eficiente cumplimiento de las funciones y la prestación de los servicios a su cargo (Corte Constitucional de Colombia, Sentencia C-1146 de 2001).

Por su parte, Buitrago (2016) ha comentado que, conforme a los principios de descentralización y autonomía de las entidades territoriales, consagrados en los artículos 1,2873, 300-4 y 313-4 de la Constitución Política confirieron a las asambleas departamentales y a los concejos municipales la posibilidad de establecer aspectos de la obligación tributaria. Según el ce, la ley puede convivir con normas expedidas por las asambleas y por los concejos, pues, en materia de impuestos, se cumpliría a cabalidad el principio de reserva de ley, entendido en sentido amplio, en cuanto que solo los órganos de representación popular pueden establecer impuestos, y una vez autorizado el impuesto por la ley nacional, corresponde a la autoridad local fijar los elementos del tributo, cuando no lo ha hecho la ley nacional (Exp. 16949 de 2011).

Ahora bien, en consideración a lo preceptuado en la Constitución Política de Colombia, la autonomía territorial como núcleo esencial de la descentralización administrativa es entendida como la facultad que tienen los departamentos, distritos y municipios para administrar los recursos de su propiedad; en este sentido, el artículo 287 de la c.P prescribe una serie de derechos para las entidades territoriales a efectos de que estas puedan gestionar sus propios asuntos y ejercer la autonomía en los siguientes términos:

Las entidades territoriales gozan de autonomía para la gestión de sus intereses, y dentro de los límites de la Constitución y la ley. En tal virtud tendrán los siguientes derechos: 1) Gobernarse por autoridades propias. 2) Ejercer las competencias que les correspondan. 3) Administrar los recursos y establecer los tributos necesarios para el cumplimiento de sus funciones. 4) Participar en las rentas nacionales.

Según el anterior precepto constitucional, la autonomía de las entidades territoriales está constituida por los poderes de acción para poder satisfacer los intereses de la entidad; en consideración al derecho de autodirigirse y gestionar sus propios recursos; en este orden de ideas, Robledo (2010) señala que "la autonomía territorial adquiere dos dimensiones: en primer lugar, la autonomía como principio fundamental de la organización del Estado; y en segundo término, la autonomía como atributo o cualidad de las entidades territoriales" (p. 45).

Por su parte, Alfonso (2015) señala que "la autonomía de las entidades territoriales se debe entender como aquella libertad que tienen para atender sus necesidades locales con recursos endógenos, siempre y cuando sus decisiones se enmarquen dentro de lo señalado por la Constitución y la ley" (p. 25). 
En este contexto, la autonomía territorial encuentra su núcleo en la identidad comunitaria local, así como su capacidad para autodeterminarse en el marco del modelo de la organización del Estado colombiano; en efecto, es importante recorrer el antecedente jurisprudencial; marco general dentro del cual se encuentra consagrado el principio de autonomía territorial, así como sus límites constitucionales, en especial los pronunciamientos referidos al suscitado artículo 287 de la Carta Política; núcleo esencial del desarrollo del principio de autonomía territorial, constituido principalmente por las competencias y derechos atribuidos a las entidades territoriales; al respecto, en la Sentencia C-517 de 1992 la Corte Constitucional efectúa el primer pronunciamiento con respecto a los límites de la autonomía territorial, en los siguientes términos:

De otra parte, es claro también que la garantía constitucional de la autonomía de las entidades territoriales tiene un contenido básico material, deducible de la Carta, el cual sirve de límite y guía a la acción del legislador, en su tarea de establecer la configuración concreta del mapa de competencias (C-517 de 1992).

\section{B. Concepto de poder tributario y límites del poder tributario en las entidades territoriales}

Antes de abordar el concepto de poder tributario, es necesario hacer alusión al poder político, el cual se entiende como la capacidad que ostenta el Estado para dirigir a sus asociados, según los fines constitucionales y las garantías del interés general ${ }^{3}$.

En este sentido, para alcanzar dichos fines, es necesario que el Estado tenga a su disposición los recursos económicos suficientes para satisfacer las necesidades de sus asociados.

Ahora bien, el poder tributario como manifestación del poder político reviste especial importancia en la consecución de recursos, dada la soberanía de sujeción de los particulares; al respecto, Bravo (2003) señala:

Como sujeto del poder tributario, el Estado representa una soberanía que mantiene bajo su sujeción a los particulares, no simplemente como una manifestación de fuerza política y jurídica, sino con la finalidad fundamental de realizar el bien común de los asociados. Por virtud de ese poder encaminado al bien común, el Estado puede y debe establecer los tributos necesarios para proveer los recursos destinados al cumplimiento de sus fines (p. 213).

3 Constitución Política de Colombia. Art 2 "Son fines esenciales del Estado: servir a la comunidad, promover la prosperidad y garantizar la efectividad de los principios, derechos y deberes consagrados en la Constitución; facilitar la participación de todos en las decisiones que los afectan y en la vida económica, política, administrativa y cultural de la Nación". 
En efecto, la potestad tributaria emanada de la Constitución, faculta al Estado, para imponer a sus asociados las cargas necesarias para que estos contribuyan con el financiamiento de los gastos destinados a la satisfacción del interés general.

Por su parte, Roberto Insignares (2015) se refiere al poder fiscal como el instrumento para la gestión de recursos, con los que el Estado materializa sus fines constitucionales, en los siguientes términos:

En la actualidad es imposible concebir el poder fiscal como una categoría unitaria derivada de la soberanía; se trata, más bien, de una fórmula abreviada para la atribución de competencias en el marco de la hacienda pública; una suerte de halo de potestades de orden constitucional, e incluso de orden administrativo, del que gozan los entes públicos en el orden central y descentralizado para la definición de un sistema que integre aquellos instrumentos que, en materia de ingreso y gasto, coadyuven al cumplimiento de los fines constitucionales (pp. 59-60).

Sumado a lo anterior, para el citado autor, el poder tributario tiene una connotación tanto de orden constitucional como administrativo que coadyuvan en el acometido de los fines del Estado.

En términos generales, Piza (2010) define el poder tributario como: "Aquella facultad que tiene el Estado de crear o establecer tributos y hacerse de recursos para el cumplimiento de los fines cuyo cumplimiento le ha asignado la Carta Política" (p. 68).

En este sentido, a través del constituyente primario, el Estado gestiona los recursos necesarios para la satisfacción de los intereses generales, pues, en palabras de Bernal (2005), la Constitución de 1991 establece al Congreso como titular del poder tributario originario, pero otorga una facultades particulares a las asambleas departamentales, concejos distritales y municipales, bajo las cuales estas corporaciones son las únicas habilitadas para establecer o votar tributos (que no sean de carácter nacional) dentro de su competencia, pero siempre con referencia directa a lo establecido por el legislador nacional, es decir, ostentan un poder tributario derivado (Bernal, 2005).

Por su parte, Cubides (2016) señala que

(...) la magnitud del poder tributario de las entidades territoriales será aquel que les dé el legislador en cada caso, puesto que no hay criterio unívoco, y en últimas es el ente legislativo el que determina en mayor o menor medida los elementos del tributo territorial (p. 78).

Ahora bien, en la Sentencia C-467 de 1993, la Corte afirma que una vez creado el impuesto, los municipios adquieren el derecho de administrarlo, manejarlo y utilizarlo en las obras y programas que consideren necesarios y convenientes para el municipio y la comunidad en general, sin que pueda el Congreso interferir en su administración, ni recortarlo, 
ni conceder exenciones, ni tratamientos preferenciales, ni extenderlos, ni trasladarlo a la Nación, salvo en caso de guerra exterior (Insignares, 2015).

En este sentido, la Corte Constitucional ha precisado que las fuentes de financiación de las entidades territoriales son por excelencia las fuentes endógenas y exógenas; las primeras dependen directamente de la participación en los recursos del Estado a través de las transferencias que recibe la entidad territorial del gobierno central, así como las regalías y la compensaciones en las que el legislador puede intervenir porque se trata de fuentes de financiación del orden nacional; las segundas se denominan fuentes endógenas, es decir, rentas que provienen de recursos propios de la entidad, lo que significa que son de su propiedad y se originan dentro de su jurisdicción y, por consiguiente, su gestión depende directamente de la entidad territorial.

De otra parte, en los términos de la Sentencia C-720 de 1999, los criterios para clasificar las rentas exógenas y endógenas dependen en primer lugar del criterio orgánico, es decir, de la decisión política que interfiere para perfeccionar la obligación tributaria; en segundo lugar, el criterio jurisdiccional que hace referencia al cobro dentro del territorio de la entidad territorial; en tercer lugar, el criterio integral del presupuesto; lo que significa que las rentas recaudadas se canalizan directamente a través de la respectiva entidad territorial, y el cuarto criterio está referido a que los elementos estructurales del tributo no corresponda a una renta nacional, a efectos de concluirse que se trata de una fuente endógena de financiación.

La jurisprudencia constitucional se ha encargado, a través de sus providencias, de centrar las bases para determinar la conexidad entre la autonomía territorial y la clasificación de las fuentes endógenas y exógenas, todas vez que los límites legales y constitucionales de la autonomía financiera de las entidades territoriales encuentra su sustento en el margen de configuración de los elementos estructurales de los tributos a partir del grado de amplitud en la intervención o no del legislador, a efectos de privar a la entidad territorial del establecimiento del tributo.

A propósito de los límites del poder tributario, tratadistas como Insignares (2015) han conceptualizado que los impuestos locales gozan de especial protección constitucional.

Sin embargo, es preciso recordar que la facultad impositiva de los entes territoriales se encuentra limitada o subordinada no solo a la Constitución sino también a la ley, según lo establecido por el inciso 3 del artículo 287.

Por su parte, Buitrago (2016) indica que el punto de partida para el establecimiento de un tributo por parte de los entes territoriales solo puede ser una ley del Congreso de la República, que los faculta a administrarlo, manejarlo y utilizarlo, y esto se ha reconocido así tanto por la sala constitucional de la Corte Suprema de Justicia (CSJ) en vigencia de la CP de 1886, refiriéndose a la iniciativa impositiva del Congreso y la facultad reglamentaria de los entes territoriales (sentencia mayo 12 de 1980), así como la Corte Constitucional en vigencia de la CP de 1991 según Sentencia C-004 de 1993, reiterada en C-467 de 1993.

Ahora bien, con respecto a la asignación de competencias al Congreso de la República para la creación modificación y extinción del tributo, Cruz de Quiñonez, citada por Bernal 
(2015), expresa que esta dualidad de origen suizo (Blumenstein), se establece en los siguientes términos:

Según si este poder emana directamente de la Constitución, sin sujeción a otros límites que los que la propia Constitución establezca, noción que corresponde al poder originario o si por el contrario ese poder aunque sea reconocido constitucionalmente debe someterse a la Ley de autorizaciones, en cuyo caso se designa como poder derivado.

En consideración a lo anterior, la autora concluye que el poder de las entidades territoriales es derivado y que el poder de las entidades territoriales se deriva de la autorización dada por la Ley:

En la medida que las entidades locales tienen autonomía para establecer los tributos en su territorio siempre y cuando exista una Ley que contenga una autorización impositiva en la cual se prevean los supuestos de hecho tipificadores del tributo, que es justamente el contenido de la competencia del Congreso (Bernal, 2015).

Ahora bien, Insignares (2015) advierte que en la Sentencia C-467 de 1993 la Corte afirma que una vez creado el impuesto los municipios adquieren el derecho a administrarlo, manejarlo y utilizarlo en las obras y programas que consideren necesarios y convenientes para el municipio y la comunidad en general, sin que pueda el Congreso interferir en su administración, ni recortarlo, ni conceder exenciones, ni tratamientos preferenciales, ni extenderlos, ni trasladarlo a la Nación, salvo en caso de guerra exterior. En este sentido los impuestos locales gozan de especial protección constitucional (Insignares, p.106).

No obstante, la jurisprudencia constitucional ha suscitado diferentes posturas en el marco de la autonomía territorial, configurándose en palabras de Perdomo (2018) tres líneas jurisprudenciales:

Línea jurisprudencial restrictiva: el poder tributario es ejercido por el legislador, quien deberá definir la integridad de los elementos estructurales del tributo, a saber: sujeto activo, sujeto pasivo, hecho generador, base gravable y tarifa; en este sentido, las entidades territoriales tienen la posibilidad de reglamentar o no reglamentar el tributo en su jurisdicción ${ }^{4}$.

Línea jurisprudencial diferenciadora: en esta ocasión, la Corte plantea la necesidad de diferenciar la facultad de creación con la simple autorización, lo que significa, en primer lugar, que el legislador está llamado a definir los elementos estructurales del tributo y la entidad territorial, la discrecionalidad de adoptar o no adoptar el tributo en su jurisdicción; 
en segundo lugar, las entidades territoriales se limitarían a efectuar la reglamentación en su territorio con un mayor margen de autonomía 5 .

Línea jurisprudencial que limita los juicios de constitucionalidad: finalmente, encontramos la tesis según la cual es imposible establecer juicios de constitucionalidad en relación con normas que crean tributos, puesto que la Ley orgánica es la que, por competencia, debe resolver la forma como órganos de representación locales y el Congreso ejercen su potestad normativa tributaria ${ }^{6}$.

En este contexto, es necesario traer a colación las diferentes posturas de la Corte Constitucional en torno al desarrollo del principio de autonomía territorial, en los siguientes términos:

Por su parte, la Sentencia C-891 de 2012 señala que las entidades territoriales gozan de autonomía para la gestión de sus intereses; adicionalmente en la Sentencia C-205 de 1995 la Corte Constitucional se refiere a la soberanía fiscal de las entidades territoriales como la capacidad para administrar sus recursos en el marco del derecho de propiedad; en este mismo sentido la Sentencia C 506 de 1995; precisa que las rentas y los bienes de propiedad de las entidades territoriales no puede ser intervenida por el poder tributario del Congreso de la República.

Ahora bien, en Sentencia C-517 de 2007, la Corte precisa que las entidades territoriales carecen de soberanía tributaria para definir los elementos estructurales del tributo; no obstante, tienen autonomía tributaria para administrar sus propios intereses en los límites de la Constitución y la ley.

Según la Sentencia C-537 de 1995, la autonomía territorial para el establecimiento de los tributos tiene sus límites en la Constitución y la ley; en este mismo sentido, en Sentencia C-321 de 2009, la Corte Constitucional determina que la autonomía de las entidades territoriales se encuentra limitada por la Constitución y la ley; es decir que no se configura el poder tributario soberano para la fijación de los elementos estructurales del tributo, y en este contexto el margen de las entidades territoriales se limita a la gestión del tributo previa aprobación en ley de autorización.

Ahora, en la Sentencia C-089 de 2001 se precisa que la autonomía de las entidades territoriales no es absoluta: la soberanía tributaria conferida por el legislador debe ser entendida en estricto sentido de acuerdo con la Constitución y la ley. En efecto, las entidades territoriales tienen autonomía con respecto a la gestión de sus recursos de su propiedad.

En este orden, la Sentencia C-1097 de 2001 prescribe que las entidades territoriales podrán reglamentar los elementos estructurales del tributo, en consideración a la ley de autorización, con el fin de salvaguardar la atomización del tributo.

De otra parte, la Sentencia C-533 de 2005 señala que la autonomía de las entidades territoriales comprende la administración de sus propios recursos y la gestión de los C-227 de 2002, C-504 de 2002, 1043 de 2002, C-517 de 2007, C-039 de 2009 
intereses para el cumplimiento de sus funciones dentro de los límites de la Constitución y la ley.

\section{Estructura tributaria del Impuesto de Industria y Comercio - ICA}

La evolución del Impuesto de Industria y Comercio en el sistema tributario se ha debido principalmente al establecimiento de gravámenes sobre actividades conexas a la actividad mercantil y a las regulaciones complementarias dentro del ordenamiento jurídico; en efecto, en la actualidad el Impuesto de Industria y Comercio grava los ingresos provenientes de actividades industriales, comerciales y de servicios en una jurisdicción territorial distrital o municipal determinada.

En consideración a la característica territorial de este tributo, sus elementos estructurales y su nominación, el Impuesto de Industria y Comercio se configura como un tributo directo del orden municipal que hace parte de las rentas endógenas de la entidad.

Los antecedentes normativos del Impuesto de Industria y Comercio se encuentran consagrados en la Ley 97 de 1913 y la Ley 14 de 1983 considerada como el marco de referencia para la determinación de los elementos estructurales.

La Ley 14 de 1983, reglamentada por el Decreto 1333 de 1986 y modificada por la Ley 75 de 1986, determina los elementos estructurales del tributo, configurándose para las entidades territoriales los efectos jurídicos vinculantes de la ley de autorización en la aplicación del tributo en sus jurisdicciones.

Para efectos del presente artículo, el análisis del Impuesto de Industria y Comercio se limita al otorgamiento de los beneficios tributarios por parte de las entidades territoriales; no obstante, a continuación, resulta importante abordar conceptualmente los elementos estructurales que revisten importancia en la comprensión jurídica del tributo.

En primera medida, los sujetos pasivos del Impuesto de Industria y Comercio son las personas naturales, las jurídicas y las sociedades de hecho, que realicen el presupuesto fáctico que da origen al nacimiento de la obligación en la jurisdicción de un municipio.

De otra parte, el hecho generador, en los términos del artículo 32 de la Ley 14 de 1983 y el artículo 195 del Decreto 1333 de 1986, define el hecho generador del impuesto como la realización de actividades comerciales, industriales y de servicios que se ejerzan o realicen en las respectivas jurisdicciones municipales, directa o indirectamente, por personas naturales y jurídicas o por sociedades de hecho, ya sea que se cumplan en forma permanente u ocasional, en inmuebles determinados, con establecimientos de comercio o sin ellos.

Es importante destacar que la norma fija algunos elementos que revisten efectos en la realización del hecho generador del Impuesto de Industria y Comercio, en los siguientes términos:

La actividad puede ser realizada de forma directamente por el sujeto pasivo o bien a través de terceros; en consecuencia, puede configurarse de forma permanente $u$ 
ocasional, no obstante, en el ordenamiento jurídico no se especifica lo que debe entenderse como actividad ocasional, posibilitando de esta manera que la entidad en el marco de la autonomía territorial lo reglamente.

De otra parte, la norma no condiciona la obligatoriedad de desarrollar actividades industriales, comerciales y prestación del servicio en un establecimiento de comercio; lo que nos lleva a inferir que la actividad puede desarrollarse en una jurisdicción con o sin establecimiento de comercio.

Por su parte, la configuración jurídica del hecho generador en el Impuesto de Industria y Comercio está constituida por la realización de actividades industriales, comerciales y prestación de servicios; en estos términos, es necesario efectuar una conceptualización por cada una de estas, en consideración a los artículos 34 a 36 de la Ley 14 de 1983.

La Ley 14 de 1983 y su Decreto reglamentario 1333 de 1986 definen las actividades industriales como las dedicadas a la producción, extracción, fabricación, confección, preparación, transformación, reparación, manufactura y ensamblaje de cualquier clase de materiales o bienes; por su parte, para los fines de la Ley 14 de 1983, se consideran actividades comerciales las destinadas al expendio, compraventa o distribución de bienes o mercancías, tanto al por mayor como al por menor, y las demás definidas como tales por el Código de Comercio siempre y cuando no estén definidas por el mismo código o por la Ley 14 de 1983 como actividades industriales o de servicios.

Ahora bien, la Ley $1819^{[7]}$ de 2016 modificó el artículo 36 de la Ley 14 de 1983, compilado en el artículo 199 del Decreto-Ley 1333 de 1986 en los siguientes términos:

Se consideran actividades de servicio todas las tareas, labores o trabajos ejecutados por persona natural o jurídica o por sociedad de hecho, sin que medie relación laboral con quien los contrata, que genere contraprestación en dinero o en especie y que se concreten en la obligación de hacer sin, importar que en ellos predomine el factor material o intelectual (Ley 1819, 2016).

El Impuesto de Industria y Comercio se considera un impuesto de periodo de causación vigencia vencida. En efecto la periodicidad del Impuesto de Industria y Comercio es anual en los municipios de Colombia con excepción de Bogotá D.C que es bimestral.

Por su parte la base gravable del Impuesto de Industria y Comercio, conforme con el artículo 342 de la Ley 1819 de 2016, que modifica el artículo 33 de la Ley 14 de 1983, define que "la base gravable está conformada por la totalidad de los ingresos ordinarios y extraordinarios percibidos en el respectivo año gravable, incluidos los ingresos obtenidos por rendimientos financieros, comisiones y en general todos los que no estén expresamente excluidos en este artículo" (Ley 1819,2016).

7 Por medio de la cual se adopta una reforma tributaria estructural, se fortalecen los mecanismos para la lucha contra la evasión y elusión fiscal, y se dictan otras disposiciones. 


\section{Exenciones y beneficios tributarios}

Los beneficios tributarios se han concebido en el ordenamiento jurídico como un instrumento que incentiva y privilegia ciertas actividades económicas; en efecto, los beneficios tributarios tienen un impacto en el hecho generador del tributo; si bien aminora la base grave, la consecuencia se enmarca en el nacimiento de la obligación tributaria, dado que no se hace posible su estructuración jurídica total o parcial.

En este sentido, la Ley 14 de 1983 en el artículo 38 fija el límite para otorgar exenciones por parte de una entidad territorial, en los siguientes términos: "Los municipios solo podrán otorgar exenciones de impuestos municipales por plazo limitado, que en ningún caso excederá de diez años, todo de conformidad con los planes de desarrollo municipal" (Ley 14 de 1983).

De tal forma, los beneficios tributarios en los sistemas tributarios territoriales se conciben como instrumentos de política fiscal que incentivan a ciertos sectores de la estructura productiva, tal como lo señala Batista (2014): "Los beneficios tributarios han sido desde hace décadas un medio para incentivar determinados sectores económicos, privilegiar sectores sociales".

Cubides (2016) señala que el establecimiento de una exención o exclusión determina que no se produzcan las consecuencias jurídicas típicas asociadas a la realización del hecho generador, lo cual, en el caso de las exenciones, se traduce en la concurrencia de dos normas: una primera que da nacimiento a la obligación sustancial tributaria al realizar el hecho generador del tributo, y otra que aminora el efecto anterior. En el caso de las exclusiones existe una norma que impide la realización del hecho generador, por lo que la obligación tributaria no nace a la vida jurídica (pp. 84-85).

Por su parte, Bautista (2014) efectúa una definición básica, en la que se puede entender en un sentido relativamente diferente en la nominación de los beneficios tributarios; precisa que los beneficios tributarios se consideran en el sistema tributario como la excepción a la regla general, lo que significa que se presentan diferencias en las tarifas aplicables, las bases gravables y su cuantificación, que en muchas ocasiones no pueden cuantificarse nominalmente.

Por último, la Corte Constitucional, en Sentencia C-540, efectúa la claridad sobre la distinción establecida por la doctrina fiscal entre beneficios tributarios y las así nominadas genéricamente minoraciones estructurales (Velarde Aramayo, 1997), en los siguientes términos:

Si bien, las minoraciones estructurarles reducen la carga impositiva o excluyen o exonera a un determinado sujeto del deber de contribuir representan simplemente un reconocimiento de los principios de tributación, y sin ellas el sistema tributario o un determinado impuesto, no podrían ser calificados a primera vista como justos equitativos y progresivos. En otras palabras, aquellas previsiones legales que solamente pretenden reconocer y hacer efectivos los más elementales principios de la tributación no 
constituyen verdaderos incentivos, sino simplemente maneras o formas de no hacer de un tributo una herramienta de castigo o un elemento de injusticia (p. 57).

Las minoraciones estructurales, a pesar de suponer un tratamiento diferente de los sujetos gravados, se caracterizan porque no tienen como propósito principal incentivar o crear preferencias sino coadyuvar a la definición y delimitación del tributo y a la aplicación práctica de los principios de tributación. Su finalidad no es incentivar, estimular o preferir determinados sujetos o actividades sino simplemente "no perjudicar", es decir, realizar los principios de justicia, equidad, progresividad y capacidad económica. Por eso operan al interior del tributo y contribuyen a la exacta definición y cuantificación del supuesto de hecho, de la base gravable y del monto de la tarifa tributaria, por lo tanto, afectan a la riqueza o al sujeto gravado con base en consideraciones que obedecen fundamentalmente a su aptitud para contribuir a sufragar los gastos públicos (p. 67).

\section{E. Clasificación de los beneficios tributarios}

Giannini (1957) clasifica los beneficios tributarios en subjetivos y objetivos; enfatiza en que los primeros se suscriben a situaciones en las cuales la ley "declara no obligada al pago del impuesto a una persona o una categoría de personas que, conforme a las disposiciones más generales de la propia ley quedarían comprendidas" (pp. 110-156).

De igual manera, Castro (2013) identifica dos tipos de exenciones: automáticas y subjetivas. Las primeras están reconocidas en la ley y no requieren la acreditación de requisito alguno por parte del contribuyente, a diferencia de las segundas que no solo deben ser solicitadas por el contribuyente para que sean reconocidas, sino también demostrar el cumplimiento de los requisitos taxativos en la norma.

Ahora bien, en el sistema tributario de las entidades territoriales, los beneficios tributarios se califican como exenciones, exclusiones, tarifas reducidas, deducciones, créditos, diferimientos, regímenes especiales, devoluciones y descuentos, los cuales tiene una connotación específica en la afectación del recaudo.

En consecuencia, los beneficios tributarios generan costos fiscales para la entidad territorial, perforando de esta manera la base gravable; en efecto, un sacrificio en el recaudo tributario, diferenciándose de esta forma de otro beneficio denominado gasto tributario, el cual es previsible por la entidad territorial, ya que su efecto se incorpora al presupuesto y obedece a una estimación real y no estadística como sí ocurre en los beneficios tributarios con costo fiscal.

La renuncia tributaria es otro de los beneficios tributarios. El efecto de la concesión de dicho beneficio repercute directamente en que el impuesto permanece en manos de quien en principio es sujeto pasivo de la obligación tributaria como consecuencia de un tratamiento preferencial (Bautista, 2014).

En efecto, Simonit (2013) señala que los beneficios tributarios presentan divergencias en su denominación, por lo que se hace compleja su compresión. La Organización para la 
Cooperación y el Desarrollo Económico - OCDE ha reconocido la variedad de beneficios tributarios y su impacto en la tributación de las personas jurídicas y naturales (Simonit, 2013).

Ahora bien, la taxonomía de los beneficios tributarios otorgados por las entidades territoriales en Colombia ha revestido especial importancia en la administración y recaudo de los tributos, como consecuencia de los tratamientos preferenciales que se suscitan en torno a la aplicación de las diferentes figuras enmarcadas en la normatividad, pues la justificación de la estructura legal de tales beneficios presenta diferentes consideraciones con respecto a la racionalización de los tratamientos preferenciales, máxime cuando se ha evidenciado que el costo fiscal disminuye la eficiencia en las actividades de fiscalización $\mathrm{y}$, por ende, la administración y recaudo del tributo.

\section{F. Antecedentes jurisprudenciales de los beneficios tributarios}

Según la jurisprudencia proferida por el Consejo de Estado, el establecimiento de las exenciones por parte de las entidades territoriales en el marco de la autonomía territorial está limitado a la ley de autorización en la que el legislador configura la norma sustantiva.

En este orden de ideas, Perdomo (2018) refiere el análisis efectuado por el Consejo de Estado con respecto al otorgamiento de tratamiento preferenciales por parte de las entidades territoriales en su jurisdicción:

El Consejo de Estado realiza un análisis relacionado con las facultades que ostentan los Concejos Municipales en materia de exenciones dentro de su territorio, todo para lo cual, realiza un análisis basado en el art. 1 de la Ley 29 de 1963, el cual expresa que únicamente los municipios pueden decretar exenciones o exoneraciones de los impuestos que por la Constitución y la Ley les corresponden (Perdomo, 2018).

Por su parte, en la jurisprudencia constitucional logra advertirse que la exención tributaria se concibe como un instrumento de política fiscal que está orientado principalmente al tratamiento impositivo diferencial para estimular propósitos económicos y políticos. En efecto, la justificación para el establecimiento de exenciones en materia tributaria por parte de las entidades territoriales debe corresponder a un fin constitucional aceptable que esté en armonía con los principios tributarios; es decir, que las entidades territoriales en el marco de la autonomía territorial no pueden modificar los elementos estructurales del tributo proferidos en la ley de autorización.

Ahora bien, en el ejercicio del poder tributario, los entes territoriales están facultados de conceder tratamientos preferenciales. Dicha facultad encuentra su sustento en preceptos de orden constitucional que se materializa a través de una norma de prohibición, en la que se precisa que son las entidades territoriales las que están facultadas para conceder exenciones o tratamientos preferenciales dentro de los límites de la Constitución y la ley. No obstante, las exenciones otorgadas por las entidades territoriales finalmente terminan 
enervando la configuración del hecho generador; frente a este supuesto de hecho, el órgano de representación popular, asambleas departamentos, concejos distritales y municipales, según su criterio, otorgan tratamientos preferenciales con sustento en normas de rango legal.

De otra parte, el principal antecedente jurisprudencial referido a la definición de los tratamientos preferenciales se encuentra en la Sentencia C-748 de 2009, en los siguientes términos:

Concretamente, a través de las exenciones tributarias, el legislador impide el nacimiento de la obligación tributaria en relación con determinados sujetos o disminuye la cuantía de la misma, por consideraciones de política fiscal. Así, si bien en principio, respecto del contribuyente, se concreta el hecho generador del tributo, este se excluye de forma anticipada de la obligación tributaria, por disposición legal mediante una técnica de desgravación que le permite al legislador ajustar la carga tributaria, de manera que consulte los atributos concretos del sujeto gravado o de la actividad sobre la que recae la obligación tributaria, siempre con sujeción a criterios razonables y de equidad fiscal.

En la Sentencia C-602 de 2015 proferida por la Corte Constitucional se definieron las exenciones en los siguientes términos: "Las exenciones tributarias corresponden a situaciones que en principio fueron objeto de gravamen pero que son sustraídas del pago -total o parcial-de la obligación por razones de política fiscal, social o ambiental".

Ahora, en lo que respecta a los propósitos fiscales en el otorgamiento de beneficios tributarios por parte de una entidad territorial, la Corte Constitucional, en Sentencia C-1107 de 2001, efectúa sus precisiones al respecto:

Los propósitos fiscales que debe perseguir una exención, son los siguientes:

1) recuperación y desarrollo de áreas geográficas gravemente deprimidas en razón de desastres naturales o provocados por el hombre; 2) fortalecimiento patrimonial de empresas o entidades que ofrecen bienes o servicios de gran sensibilidad social; 3 ) incremento de la inversión en sectores altamente vinculados a la generación de empleo masivo; 4) protección de determinados ingresos laborales; 5) protección a los cometidos de la seguridad social; 6) en general, una mejor redistribución de la renta global que ofrece el balance económico del país (C-1107 de 2001).

Según los preceptos jurisprudenciales en comento, los tratamientos diferenciales otorgados por las entidades territoriales deberán corresponder a razones admisibles desde la perspectiva constitucional; en este sentido, la ruptura de principios deberá corresponder a una adecuada justificación; en la Sentencia C-799 de 1999 se precisa lo siguiente: “(...) el juez de constitucionalidad debe verificar si tal exclusión de la carga impositiva encuentra 
adecuada justificación, ya que, de lo contrario, afectaría el principio constitucional de la igualdad. Y también ha de establecer si se consagran".

En este contexto, los tratamientos preferenciales deberán estar fundados en razones objetivas que implican una decisión responsable para la entidad territorial. En efecto, las decisiones de política fiscal están limitadas por los preceptos constitucionales.

Según el antecedente jurisprudencial analizado, las exenciones otorgadas por las entidades territoriales no podrán modificar los elementos esenciales fijados por el legislador en consideración a que las exenciones inciden directamente en el presupuesto de hecho que da origen a la obligación tributaria.

En consecuencia, Perdomo (2018) señala:

(...) en un país con 1.123 municipios y 32 departamentos, resulta acertado decir que puede haber tantos criterios para establecer una exención como entes territoriales hay, pero más allá del buen criterio de política fiscal que puedan llegar a tener los entes territoriales, el asunto que nos interesa es que, como se explicó, las exenciones tienen una incidencia directa en el hecho generador, lo cual desde el punto de vista de la Constitución puede constituirse en una facultad que desborda la autonomía territorial en detrimento del principio de reserva de Ley, pues este se predica de los elementos esenciales del tributo.

\section{G. Reconocimiento de los beneficios tributarios en los impuestos territoriales}

Según Acevedo (2016), el reconocimiento de beneficios en los tributos municipales es asunto del ente territorial. Así se desprende del artículo 294 de la Constitución, en el que se prohíbe al legislador conceder exenciones o tratamientos preferenciales en relación con los tributos de las entidades territoriales. Obviamente, no se trata de un poder absoluto, pues en el reconocimiento de una exención, los concejos deben respetar, además de los límites fundamentales, un límite temporal establecido por el artículo 38 de la Ley 14 de $1983^{[8]}$ (Acevedo, 2016).

Sobre lo anterior, la exención en materia tributaria comprende aspectos de trascendencia constitucional para la configuración de una soberanía tributaria limitada, con fundamento en el poder de imposición y sus implicaciones fiscales.

En este orden de ideas, una entidad territorial puede establecer preferencias para los contribuyentes con respecto a impuestos territoriales de su propiedad, es decir que la

8 Artículo 38 Ley 14 de 1983. Los municipios solo podrán otorgar exenciones de impuestos municipales por plazo limitado, que en ningún caso excederá de diez años, todo de conformidad con los planes de desarrollo municipal. 
entidad territorial, mediante su autonomía fiscal, puede otorgar beneficios tributarios en su jurisdicción; tal como se infiere del artículo $294^{[9]}$ de la Carta Política.

En este contexto, los beneficios tributarios implican sacrificios en el recaudo para la Administración tributaria territorial, pues la entidad territorial implícitamente asume en sus finanzas el costo fiscal, dando lugar a que el tributo permanezca en las arcas del contribuyente como consecuencia del tratamiento preferencial.

No obstante, en el ordenamiento jurídico colombiano se puede advertir, que mediante la Ley 819 de $2003^{[10]}$, en el artículo 5 literal e y el artículo 7, se incorporan al sistema tributario Requisitos adicionales a los ya suscitados en el artículo 38 de la Ley 14 de 1983 y el artículo 258 del Decreto reglamentario 1333 de $1983^{[11]}$.

\section{Análisis de las exenciones y beneficios tributarios para el ICA en los mu- nicipios de Guarne y Rionegro en el Valle de San Nicolás, oriente antio- queño en el periodo 2008 al 2017}

Una vez abordados los antecedentes doctrinales y jurisprudenciales referidos a la descentralización, el poder tributario de las entidades territoriales y su incidencia para el otorgamiento de beneficios tributarios en el Impuesto de Industria y Comercio; el presente acápite en primer lugar busca contextualizar la posición geográfica y económica de los municipios objeto de estudio.

De tal modo, se procederá con el análisis de la estructura jurídica de las exenciones otorgadas por los municipios de Guarne y Rionegro en el oriente antioqueño, el asentamiento industrial y sus efectos en el mercado laboral, así como el comportamiento para las vigencias comprendidas entre los años 2008 y 2017.

\section{A. Contexto Valle de San Nicolás}

El oriente antioqueño es la segunda subregión más poblada del Departamento de Antioquia después del Valle de Aburrá ${ }^{12}$. Está conformado por 23 municipios, entre los cuales se encuentran Rionegro y Guarne, el primero, considerado el segundo centro urbano más importante en la jerarquía urbana departamental.

9 Artículo 294. La ley no podrá conceder exenciones ni tratamientos preferenciales en relación con los tributos de propiedad de las entidades territoriales. Tampoco podrá imponer recargos sobre sus impuestos salvo lo dispuesto en el artículo 317.

10 Ley 819 de 2003 "Por la cual se dictan normas orgánicas en materia de presupuesto, responsabilidad y transparencia fiscal y se dictan otras disposiciones", también conocida como el marco fiscal de mediano plazo.

11 Se establecen los límites legales para la concesión de beneficios fiscales por parte de las entidades territoriales, así como la medición del costo fiscal que representan los beneficios y exenciones tributarias.

12 Anuario Estadístico de Antioquia, 2018. 


\section{Ilustración 1: División política Valle de San Nicolás}

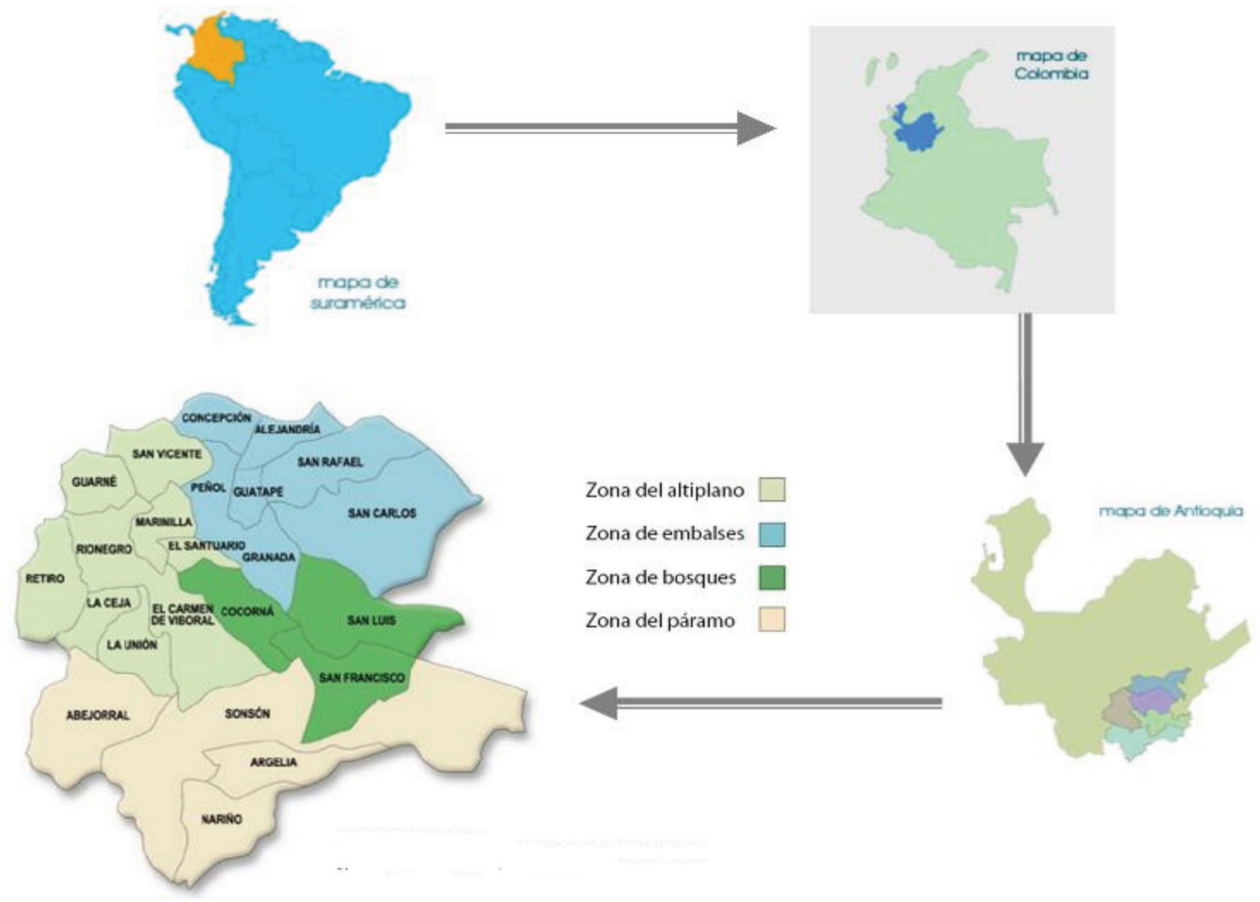

Fuente: Cámara de Comercio del oriente antioqueño.

Interesa a este estudio la zona del Altiplano donde se encuentra el denominado Valle de San Nicolás, que comprende los municipios de Rionegro, Marinilla, El Carmen de Viboral, El Retiro, El Santuario, Guarne, La Ceja, La Unión y San Vicente. Esta zona es el yacimiento de la mayor parte de los ríos que abastecen los embalses para la generación energética, además cuenta con aeropuerto internacional, zona franca y presenta la más alta tasa de densidad vial de Antioquia $\left(362,6 \mathrm{~m} / \mathrm{Km}^{2}\right)^{13}$, con una proporción de vías pavimentadas equivalentes al 17,12\% frente al 16,8 del departamento (CCOA; 2017).

En los últimos años, el Valle de San Nicolás como subregión del oriente antioqueño ha sufrido grandes transformaciones producto de una mayor industrialización, urbanización, instalación de fincas destinadas al recreo, ubicación de centros comerciales y centros de comercio en áreas que antes fueron de producción campesina; lo cual presupone una transformación del sistema tributario, ya que los municipios que componen esta subregión, en especial los que se encuentran cercanos al área metropolitana del Valle de Aburrá, presentan un mejor desarrollo económico y social por su proximidad con Medellín y su área metropolitana, generando una relación de interdependencia con la gran ciudad del Valle

13 Diagnóstico de competitividad del oriente antioqueño-CCOA, 2017. 
de Aburrá en su proceso de desarrollo y de ocupación del territorio que le ha generado beneficios significativos que han marcado su devenir (CCOA, 2017).

Desde el inicio de estas relaciones de interdependencia entre los dos valles, se creó el mito de la región del oriente cercano como "segundo piso de Medellín”, entendiendo como la opción más cercana para el crecimiento de la ciudad capital que, dadas sus condiciones geográficas, cuenta con poco suelo para su expansión.

El oriente antioqueño es la subregión de Antioquia con más ventajas comparativas y competitivas $^{14}$, por su posición geográfica estratégica y por su infraestructura vial, industrial y de prestación de servicios, que tienen gran impacto en la transformación de esta zona del oriente antioqueño. Sin lugar a dudas, la desconcentración industrial es un factor importante de generación de empleo, construcción de corredores industriales y zona francas, pero que a su vez marcó el inicio de la ocupación del suelo rural por usos urbanos. La construcción de infraestructura vial de conexión entre los dos valles, y con el centro del país, Autopista Medellín - Bogotá, carretera de Las Palmas, mejoramiento vial de Las Palmas y el túnel de oriente, así como el aeropuerto José María Córdova y otras actividades desencadenadas por la presencia del mismo en la zona le han generado al Valle de San Nicolás una ventaja competitividad al contar con una conexión al país y al mundo en su territorio; en este orden la expansión de instituciones universitarias (EAFIT, Universidad de Antioquia, Escuela de Ingeniería de Antioquia, Universidad Católica de Oriente), ha posibilitado el desarrollo de centros de investigación tecnológica e instalaciones hospitalarias, entre otras, que dotan la región de capacidad de soporte para el desarrollo y el crecimiento (CT, 2012).

Jaramillo (2007) manifiesta que el oriente es la región más integrada a la nación debido a la ubicación geográfica, a la variedad de actividades económicas, y porque produce el $33 \%$ de energía eléctrica del país. Igualmente, la ubicación geográfica de la región la hace un lugar de tránsito obligatorio de mercancía proveniente del centro de Antioquia hacia otros departamentos del país, como Tolima, Huila, Cundinamarca y Valle del Cauca (p. 1).

\section{B. Exenciones y beneficios tributarios en los municipios de Guarne y Rionegro entre los años 2008-2017}

Los beneficios tributarios otorgados por las entidades territoriales en el marco de la autonomía territorial son considerados como instrumentos para incentivar el desarrollo económico y social de las jurisdicciones. Los municipios, según preceptos constitucionales, se consideran como entidades descentralizadas; en efecto, tienen la facultad para administrar y gestionar sus propios recursos.

14 Gobernación de Antioquia, Alcaldía de Medellín, Área Metropolitana - Tres Valles: el territorio de la economía. Una estrategia de ordenamiento económico-territorial para los valles de Aburrá, Occidente Cercano y San Nicolás, en Antioquia. 
En consideración al artículo 38 de la Ley 14 de 1983, el establecimiento de los beneficios tributarios por parte de las entidades territoriales estará limitada por el término de diez años, tiempo en el cual un ente territorial podrá otorgar exenciones. Lo que significa, en nuestro entender, que la entidad territorial deberá condicionar el tratamiento preferencial al periodo de tiempo establecido en el acuerdo municipal y, en este mismo sentido, la entidad deberá establecer los requisitos para acceder a los beneficios.

La vocación industrial del Valle de San Nicolás ha posibilitado la transformación del territorio, generando cambios significativos en la estructura productiva de la región; posicionándose de esta manera como atractiva para el asentamiento empresarial y, en efecto, propiciando la competencia fiscal entre jurisdicciones para atraer contribuyentes a través de tratamientos preferenciales.

A continuación se efectúa el análisis de los beneficios tributarios en ICA en los municipios del Valle de San Nicolás; orientado al análisis de los efectos del asentamiento empresarial en los municipios de Rionegro y Guarne en consideración a sus características económicas y su desempeño fiscal; no obstante, debido a las discusiones que se pueden dar alrededor de los beneficios tributarios en materia de Impuesto de Industria y Comercio, en este aparte se pretende mostrar de manera ejemplificativa el contenido de los acuerdos que reglamentan beneficios tributarios; para tal fin, se hizo una revisión inicial por medios electrónicos, a efectos de rastrear los acuerdos municipales que permiten acceder a beneficios fiscales en los municipios objeto de estudio y los efectos en el recaudo tributario y el mercado laboral en las dos jurisdicciones que están mejor posicionadas según el desempeño fiscal del año 2017.

Figura 1: Gráfica Categorización Ley 617 de 2000

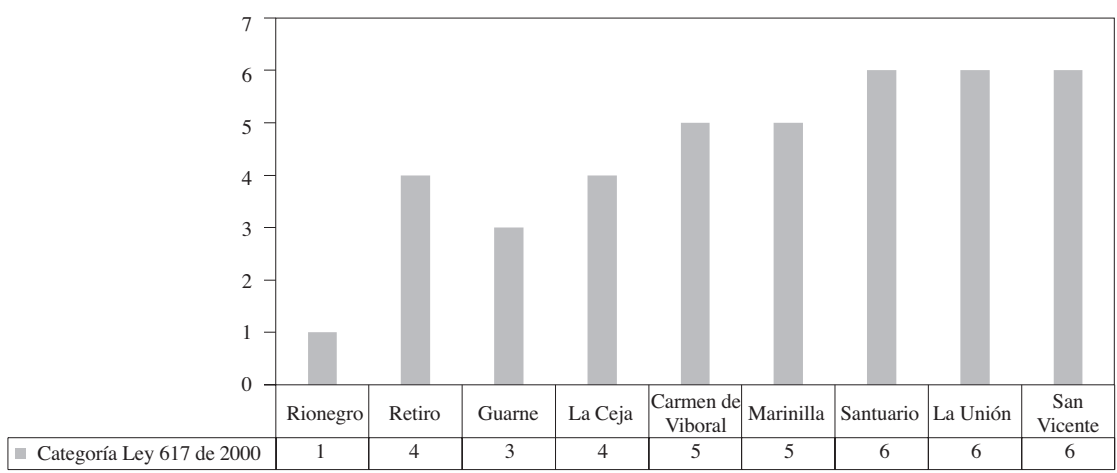

Fuente: DNP Desempeño fiscal año 2017.

En el anterior gráfico se puede observar que a partir del Indicador de Desempeño Fiscal, el DNP ordena los puntajes obtenidos para todas las entidades territoriales del país, derivando así un ranking que categoriza de mayor a menor los puntajes obtenidos; en este orden, 
para el año 2017, el Municipio de Rionegro se encuentra en categoría primera; El Retiro, categoría cuarta; Guarne, categoría tercera; La Ceja, categoría cuarta; El Carmen de Viboral, categoría quinta; Marinilla, categoría quinta; El Santuario, categoría sexta; La Unión, categoría sexta, y San Vicente Ferrer, categoría sexta.

Es así que para dar cumplimiento a los objetivos de este acápite, en primer lugar se hace una breve descripción de los beneficios tributarios otorgados por los municipios de Guarne y Rionegro en el Valle de San Nicolás para incentivar el asentamiento empresarial en el periodo 2008-2017, y, en segundo lugar, se efectúa el análisis de la información reportada por los municipios objeto de estudio en el Consolidador de Hacienda e Información Pública -CHIP- a efectos de evaluar el comportamiento de los ingresos por concepto de industria y comercio; posteriormente, se efectúa el análisis del asentamiento empresarial en los municipios de Guarne y Rionegro a partir de los informes publicados por la Cámara de Comercio del oriente antioqueño en el periodo 2008-2017, y finalmente se determina la incidencia del asentamiento empresarial en mercado laboral de los municipios de Guarne y Rionegro.

\section{TABLA 1. NORMOGRAMA ACUERDOS QUE OTORGAN BENEFICIOS TRIBUTARIOS}

EN EL PERIODO 2008 AL 2017

\begin{tabular}{|c|c|c|c|}
\hline Municipio & \multicolumn{3}{|c|}{ Norma acuerdos municipales } \\
\hline Guarne & Acuerdo n .059 del año 2008. & Acuerdo nº 004 del año 2013. & Acuerdo nº. 007 del año 2016. \\
\hline Rionegro & Acuerdo n ${ }^{\circ} .029$ del año 2005. & Acuerdo ${ }^{\circ} .063$ del año 2012. & Acuerdo $n^{\circ} .009$ del año 2014. \\
\hline
\end{tabular}

Fuente: Elaboración propia.

\section{Exenciones y beneficios tributarios Municipio de Guarne}

A continuación se efectúa el análisis de los beneficios tributarios en ICA en el Municipio de Guarne, en consideración al contenido de los acuerdos que reglamentan beneficios tributarios vigentes desde el año 2008 al 2017; para tal fin, se hizo una revisión inicial por medios electrónicos a efectos de rastrear los acuerdos municipales que permiten acceder a beneficios fiscales propiciados en el marco del asentamiento empresarial, los efectos en el recaudo tributario y el mercado laboral.

\section{AnÁlisis DE LAS EXENCIONES DEL ACUERdo MUNICIPAl 059 DEL AÑo 2008}

En el Municipio de Guarne, mediante el Acuerdo municipal 059 de 2008, se reglamentó una serie de beneficios tributarios en el Impuesto de Industria y Comercio para fomentar el asentamiento de industrias en la jurisdicción, con el fin de promover el empleo y desarrollo económico en el municipio; el beneficio tributario de que trata el acuerdo en comento será concedido a partir de la fecha en que sea aprobado por el Comité de Asentamientos 
Industriales, previo cumplimiento de todos los requisitos legales y de la Constitución en los siguientes términos:

Las nuevas empresas ${ }^{15}$ que se asienten en jurisdicción del Municipio de Guarne deberán, además de los requisitos generales, cumplir con los lineamientos establecidos en el plan básico de ordenamiento territorial, las normas estatutarias y ambientales vigentes.

Los incentivos tributarios en el Impuesto de Industria y Comercio se concederán por una sola vez a partir del inicio de la actividad productiva ${ }^{16}$; la nueva industria se someterá a pagar el impuesto de forma progresiva: durante el primer y segundo año el $0 \%$, por el tercer y cuarto año el $25 \%$, por el quinto y seis el $50 \%$, por los años siete y ocho el $75 \%$ y finalmente a partir del año nueve y diez el $100 \%$.

En este contexto, las nuevas industrias que pretendan acogerse a los beneficios establecidos deberán presentar la declaración del Impuesto de Industria y Comercio para la liquidación y revisión de la Secretaría de Hacienda Municipal.

En la siguiente tabla se ilustra el período, porcentaje de cobro del Impuesto de Industria y Comercio, y los requisitos para la obtención del beneficio tributario:

Tabla 2. Exención tributaria en el Impuesto de Industria y Comercio para nuevas empresas asentadas en el Municipio de Guarne durante los Periodos 2008-2013

\begin{tabular}{|l|c|l|}
\hline \multicolumn{1}{|c|}{ Periodo } & $\begin{array}{c}\text { \% de cobro Impuesto de } \\
\text { Industria y Comercio }\end{array}$ & $\begin{array}{l}\text { Requisito (nativo, oriundo del Municipio de Guarne o } \\
\mathbf{5} \text { años de residencia comprobada) }\end{array}$ \\
\hline Años 1 y 2 & $0 \%$ & Inicio de la actividad productiva. \\
\hline Años 3 y 4 & $25 \%$ & $\begin{array}{l}40 \% \text { del total de la mano de obra no calificada y 20\% del } \\
\text { total de la mano de obra calificada. }\end{array}$ \\
\hline Años 5 y 6 & $50 \%$ & $\begin{array}{l}50 \% \text { del total de la mano de obra no calificada y } 25 \% \text { del } \\
\text { total de la mano de obra calificada. }\end{array}$ \\
\hline Años 7 y 8 & $75 \%$ & $\begin{array}{l}\text { 60\% del total de la mano de obra no calificada y } 30 \% \text { del } \\
\text { total de la mano de obra calificada. }\end{array}$ \\
\hline Años 9 y 10, siguientes & $100 \%$ & Declaración y pago de impuestos en forma oportuna. \\
\hline
\end{tabular}

Fuente: Acuerdo municipal de Guarne nº 059 de 2008

Como se puede observar en la tabla anterior, la contratación de personal deberá cumplir con los siguientes requisitos: a partir del tercer y cuarto año de haber iniciado la actividad productiva su planta de personal de mano de obra no calificada deberá estar conformada

15 Entiéndase como empresa nueva, aquella que se asiente en el municipio por primera vez y se registre en la Secretaría de Hacienda Municipal, previo el lleno de los requisitos exigidos por la ley y los acuerdos municipales.

16 Entiéndase como inicio de la actividad productiva el proceso mediante el cual se inicia la transformación de una materia prima en producto terminado. 
por mínimo el $40 \%$ de los nativos, oriundos o en su defecto residentes que no lleven menos de 5 años de residencia comprobada en jurisdicción del municipio; así mismo, la mano de obra calificada en un porcentaje no inferior al 20\%; en los mismos términos, para el quinto y sexto año deberá contratar el $50 \%$ del total de la mano de obra no calificada y $25 \%$ del total de la mano de obra calificada; para los años siete y ocho deberá contratar el $60 \%$ del total de la mano de obra no calificada y $30 \%$ del total de la mano de obra calificada y, finalmente, para los años nueve y diez deberá presentar y pagar oportunamente la declaración del Impuesto de Industria y Comercio.

En los anteriores términos, el Acuerdo 059 de 2008 efectúa la siguiente aclaración:

(...) entiéndase como mano de obra no calificada el personal que labora como operario y oficios varios en la parte productiva y mano de obra calificada el personal que labora en la parte administrativa y el personal calificado como tecnólogo o profesional del área productiva.

Se puede evidenciar, entonces, la correlación existente entre el beneficio y los requisitos para acceder a los incentivos tributarios otorgados por la entidad territorial para el establecimiento de nuevas industrias; en este contexto, se observa que para los años uno y dos, no estará condicionado el beneficio a la contratación de personal como consecuencia del tiempo estimado que otorga la entidad territorial para el montaje y puesta en marcha de la nueva industria dentro de la jurisdicción; no obstante, en los años uno y dos, el 50\% de la mano de obra calificada y no calificada deberá ser del Municipio de Guarne, en el desarrollo de la actividad constructiva.

A partir del tercer año, se evidencia una relación directa entre el beneficio tributario y la generación de empleo; requisito ineludible para acceder al incentivo tributario para lo cual el Comité de Asentamientos Industriales hará un seguimiento trimestral, para garantizar el cumplimiento de dichos requisitos.

Es de anotar que antes de la expedición del acuerdo en comento, el Municipio de Guarne habitualmente otorgó beneficios tributarios, en cuyo contenido se puede evidenciar la misma configuración jurídica antes descrita.

Ahora bien, para el caso de las industrias preexistentes en un municipio diferente al Municipio de Guarne que desee trasladarse a desarrollar sus actividades a la jurisdicción, para acceder a los beneficios deberá tener la aprobación del comité de Asentamientos Industriales del Municipio, así mismo deberá estar a paz y salvo por todo concepto con el municipio y deberá cumplir estrictamente con las normas ambientales y de producción limpia; en caso de que la empresa sea sancionada por problemas ambientales, perderá todos los beneficios tributarios que le haya otorgado la entidad territorial. 


\section{AnÁlisis de LAS eXenCIONES DEl ACUERDo MUNICIPAL 004 DE 2013}

Por su parte, a través del Acuerdo 004 de 2013 se establecen incentivos tributarios en el Impuesto de Industria y Comercio con el fin de promover el empleo y el desarrollo económico en el Municipio de Guarne; en efecto, para aquellas empresas industriales, que se asienten en el Municipio de Guarne y que pretendan acceder a los beneficios deberán cumplir y acreditar la totalidad de los requisitos generales y especiales contenidos en la reglamentación.

En este orden, se establecen lineamientos para acceder a los beneficios tributarios otorgados por la entidad territorial, en los siguientes términos:

Progresividad en el pago del Impuesto de Industria y Comercio; las empresas nuevas ${ }^{17}$ que se asienten en jurisdicción del Municipio de Guarne, una vez cumplan con el lleno de requisitos exigidos estarán exentas en el primer y segundo año, en un 100\% del Impuesto de Industria y Comercio; para el tercer año la exención prevista será del $50 \%$ del pago del impuesto, para el cuarto año la exención será del 41\%, finalmente en el quinto año; la nueva industria estará obligada a pagar la totalidad del Impuesto de Industria y Comercio; nótese que el beneficio tributario consagrado está limitado a un periodo de tiempo determinado, en un horizonte de cinco años.

Los incentivos tributarios previstos, estarán condicionados a la generación de nuevos empleos por parte de la nueva industria; de esta forma a partir del segundo año de haber accedido a la exención, el beneficiario del incentivo deberá acreditar ante el comité de asentamientos industriales del municipio, que el $15 \%$ de la planta de personal contratada por la nueva industria corresponde a personal nativo o que en su defecto se encuentra domiciliado en jurisdicción del Municipio de Guarne dentro de los cinco años anteriores a la contratación; a partir del tercer año la contratación no puede ser inferior al 30\%; en efecto, a partir de este periodo hasta finalizar el beneficio no podrá disminuirse la proporción, so pena de perder el beneficio ; es de anotar que la exención prevista no se hace extensiva al impuesto complementario de avisos y tableros.

En los siguientes términos, el acuerdo municipal bajo análisis establece los requisitos que deben cumplir las nuevas empresas que se asienten en jurisdicción del Municipio de Guarne:

Los contribuyentes interesados en los incentivos tributarios para nuevas empresas que se asienten en jurisdicción del Municipio de Guarne, deberán presentar solicitud por escrito firmada por el contribuyente, su representante legal o apoderado debidamente constituido, para el caso de los beneficios de las personas jurídicas, deberá adjuntar copia de los estatutos de la entidad y acreditar la existencia y representación

17 Se entiende como empresa nueva aquella que se instala en el Municipio de Guarne por primera vez, la cual se debe registrar en la Secretaría de Hacienda Municipal, previo el lleno de los requisitos fijados en la ley y en los Acuerdos Municipales. 
legal, además la entidad o persona interesada, debe estar matriculado como contribuyente del Impuesto de Industria en jurisdicción del Municipio de Guarne y que se encuentre al día en el pago por concepto del respectivo impuesto o en su defecto le haya concedido facilidades para el pago, caso en el cual deberá estar al día, de lo contrario perderá el beneficio.

Adicionalmente, las nuevas empresas que pretendan acceder a los beneficios antes suscitados deberán presentar ante la Secretaría de Hacienda los siguientes documentos:

Detalle del número de empleos directos en planta que la empresa garantice generar, con Copia de afiliación a la seguridad social; certificado de la Secretaría de Planeación Municipal, con visto bueno de ubicación y uso de suelos; concepto emitido por Cornare $^{18}$ o la autoridad competente donde conste que está cumpliendo con los requisitos y recomendaciones ambientales técnicas para evitar o reducir al mínimo sus efectos contaminantes o perjudiciales y acta de aprobación del comité de Asentamientos Industriales del municipio.

Como se puede observar, las empresas nuevas que accedan a los beneficios tributarios para el reconocimiento y tratamiento preferencial en el Impuesto de Industria y Comercio en el marco del Acuerdo 004 de 2013 deberán cumplir con una serie de requisitos formales, que además incluye el cuidado del medioambiente.

En este sentido, la norma local condiciona el tratamiento preferencial a una serie de obligaciones y deberes formales, como presentar anualmente la declaración privada correspondiente al Impuesto de Industria y Comercio dentro de los 4 primeros meses del año, actualizar frente a cualquier cambio el registro de información tributaria, así como cumplir estrictamente con las normas ambientales y de producción limpia; en el evento en que la empresa beneficiada presente problemas ambientales, perderá el beneficio. Finalmente, deberá suministrar toda la información que sea requerida por la administración tributaria. Es de anotar que el acuerdo municipal preceptúa lo siguiente:

(...) cuando los contribuyentes con tratamiento especial y exenciones del pago de Industria y Comercio, no cumplan con los requisitos les será suspendido el beneficio por el respectivo año, lo que dará lugar al cobro del impuesto de Industria y Comercio y a las sanciones correspondientes.

En la siguiente tabla se sintetiza la progresividad de las exenciones tributarias en el Impuesto de Industria y Comercio para nuevas empresas asentadas en el Municipio de Guarne durante los periodos 2014-2016.

18 Corporación autónoma regional Rionegro Nare - autoridad ambiental en el oriente antioqueño. 
Tabla 3. Exención tributaria en el Impuesto de Industria y Comercio para nuevas empresas asentadas en el Municipio de Guarne durante los Periodos 2014-2016

\begin{tabular}{|c|c|c|c|c|c|}
\hline \multicolumn{1}{|c|}{ Beneficio tributario } & Año 1 & Año 2 & Año 3 & Año 4 & \multicolumn{1}{|c|}{ Año 5 } \\
\hline $\begin{array}{l}\text { Asentamiento de nuevas empresas - Acuer- } \\
\text { do 004 de 2013. }\end{array}$ & $100 \%$ & $100 \%$ & $50 \%$ & $41 \%$ & $\begin{array}{l}\text { Tarifa plena a partir } \\
\text { del quinto año }\end{array}$ \\
\hline
\end{tabular}

Fuente: Elaboración propia con información del Acuerdo municipal de Guarne n. 004 de 2013.

\section{ANÁLISIS DE LAS EXENCIONES DEL ACUERDO MUNICIPAL 007 DE 2016}

Mediante el Acuerdo 007 de 2016 se reglamenta en jurisdicción del Municipio de Guarne el tratamiento preferencial para el asentamiento de empresas pertenecientes a los sectores de educación, salud, ciencia y tecnología.

Llama la atención que el incentivo esté directamente dirigido al desarrollo de ciertas actividades en jurisdicción del Municipio de Guarne, siempre y cuando se acojan a los lineamientos establecidos en la Ley 1429 de 2010 sobre formalización y generación de empleo. De tal forma se consideran como requisitos adicionales a los habitualmente establecidos en el antecedente normativo del Municipio de Guarne; los lineamientos establecidos en el Рвот (Plan Básico de Ordenamiento Territorial), las normas estatutarias y ambientales.

La norma en comento reglamenta la progresividad en el pago del Impuesto de Industria y Comercio, bajo las siguientes consideraciones: en el primer año de operaciones la exención aplicará sobre el 100\% del pago del Impuesto de Industria y Comercio; para el segundo año la exención aplicará sobre el 75\% del pago del Impuesto de Industria y Comercio siempre y cuando el beneficiario demuestre que el $15 \%$ de los empleos están ocupados por personas nativas del Municipio de Guarne o residenciados en Guarne desde hace mínimo cinco (5) años; para el tercer año la exención será del 50\% el pago del Impuesto de Industria y Comercio, siempre y cuando el beneficiario demuestre que el $30 \%$ de los empleos están ocupados por personas nativas del Municipio de Guarne o residenciados desde hace mínimo cinco (5) años; finalmente, el 25\% de exención en el pago del impuesto de industria por el cuarto año, siempre y cuando la empresa demuestre que el $30 \%$ de los empleos están ocupados por personas nativas del Municipio de Guarne o residenciados desde hace mínimo cinco (5) años.

Es de anotar que con la expedición del Acuerdo 007 de 2016 se debe entender como empresa nueva, aquella que se instale en el municipio por primera vez, con establecimiento de comercio nuevo, que no conlleve sustitución patronal y se registre en la Secretaría de Hacienda Municipal, previo el lleno de los requisitos exigidos por la ley y los acuerdos municipales. Así mismo por disposición expresa se limita la exención al Impuesto de Industria y Comercio. 


\section{ANÁlisis DEL RECAUdO DE INDUSTRIA Y COMERCIO \\ DESDE EL AÑo 2008 al 2017 EN EL Municipio de GuARne}

Los incentivos que ofrece esta región promueven no tanto la iniciativa de empresas asentadas en el oriente antioqueño, sino también el desarrollo, proporcionando nuevas fuentes de trabajo, donde se generen los insumos y factores para un bien común.

Es así como para las entidades territoriales es de vital importancia el recaudo de sus tributos, debido a que cada municipio tiene la autonomía de administrar y disponer de ellos.

En este sentido, mediante el desarrollo del presente objeto de estudio y la información suministrada por la entidad, se evidencia que el Municipio de Guarne en la estructura de sus estados financieros tiene clasificados sus ingresos fiscales en tributarios y no tributarios; sin embargo, dentro de la suscitada estructura no se tiene clasificado el rubro de los ingresos por Impuesto de Industria y Comercio; por esta razón, se proyecta la información de acuerdo con los datos registrados por el chIP; esto se debe a que la información suministrada a esta plataforma sí cuenta con la discriminación de cada uno de los rubros que componen los ingresos del municipio, donde se refleja el Impuesto de Industria y Comercio.

Es así como en la siguiente tabla se muestran los ingresos obtenidos por el rubro objeto de estudio para el Municipio de Guarne en el periodo comprendido entre los años 2008 y 2017.

\section{Tabla 4. Ingresos tributarios de industria y Comercio}

A PRECIOS CORRIENTES PERIODO 2008-2013

\begin{tabular}{|l|c|c|c|}
\hline \multicolumn{1}{|c|}{ Periodo } & Ingreso -Industria y Comercio & Variación absoluta & Variación relativa \\
\hline 2008 & $1,618,631$ & 0 & $0.00 \%$ \\
\hline 2009 & $1,560,970$ & $-57,661$ & $-3,56 \%$ \\
\hline 2010 & $2,497,404$ & 936,434 & $59,99 \%$ \\
\hline 2011 & $2,768,875$ & 271,471 & $10,87 \%$ \\
\hline 2012 & $3,020,949$ & 252,074 & $9,10 \%$ \\
\hline 2013 & $4,304,880$ & $1,283,931$ & $42,50 \%$ \\
\hline 2014 & $4,676,189$ & 371,309 & $8,63 \%$ \\
\hline 2015 & $6,778,041$ & $2,101,852$ & $44,95 \%$ \\
\hline 2016 & $7,348,476$ & 570,435 & $8,42 \%$ \\
\hline 2017 & $11,507,469$ & $4,158,993$ & $56,60 \%$ \\
\hline
\end{tabular}

Fuente: Elaboración propia con base en información tomada del CHIP.

En la tabla 4 se pueden observar los ingresos tributarios por industria y comercio del municipio durante los periodos 2008 - 2013, para este periodo estaba en vigencia el Acuerdo 
059 del 2008, el cual contemplaba exenciones hasta por ocho años y está condicionado de la siguiente manera:

Del primer año al octavo entre el $0 \%$ y el $75 \%$ del impuesto, y a partir del noveno año el $100 \%$ del impuesto a cargo, es decir, se paga la tarifa plena, siempre y cuando cumpla los requisitos de generación de empleo.

En este mismo sentido, los ingresos durante los años 2008-2013 muestran una tendencia creciente, a excepción del año 2009, cuando se presenta una disminución en el Impuesto de Industria y Comercio del 3,56\%.

Para los años 2009-2010 se registró un crecimiento significativo en el Impuesto de Industria y Comercio con una variación absoluta del 59,99\%; entre los años 2010-2011 creció un 10,87\% para el Impuesto de Industria y Comercio; para los años 2011-2012 creció un $9,10 \%$ y, por último, entre el año 2012 y el 2013 creció un 42,50\%.

Para los periodos 2014-2016, en vigencia el Acuerdo 04 de 2013, el cual contempla exenciones hasta por cinco años que denota en su mayoría beneficios monetarios del $100 \%$ sobre Impuesto de Industria y Comercio hasta el tercer año, y algunas hasta el quinto año de acuerdo con la nueva estructura especial que se les da a los beneficios, ya que mediante este acuerdo se motiva la creación de empresas de sectores económicos específicos.

Sus ingresos continúan incrementando de un año a otro, específicamente para el año 2014, cuando tuvo una variación relativa del 8,63\% respecto al año 2013 para el impuesto de industria, en los años 2014-2015 incrementó un 44,95\%, y por su parte en los años 2015-2016 incrementó un 8,42\% para el Impuesto de Industria y Comercio.

Como se puede observar, para el año 2017 el recaudo por concepto de industria y comercio tuvo un crecimiento bastante significativo equivalente a un 56,60\% por concepto de industria y comercio; este crecimiento se dio ya que algunas empresas que tenían beneficios ya lo habían terminado para este periodo, las cuales empezaron a pagar la tarifa plena del impuesto, sumado al aumento en el número de empresas asentadas.

Otra de las causas que llevó a incrementar los ingresos tributarios fue la promulgación de la Ley 1819 de 2016, mediante la cual se introdujeron cambios importantes en lo concerniente al Impuesto de Industria y Comercio, se efectuaron aclaraciones de algunos aspectos que generaban discusión, como es el tema de territorialidad ${ }^{19}$, ya que muchas industrias que tenían varios establecimientos de comercio declaraban todos sus ingresos en la ciudad donde tenían su principal sede comercial; a través de la entrada en vigencia de esta ley se determinó, mediante el artículo 343 del ET, que la territorialidad se enmarca

19 Territorialidad: Un determinado municipio solo puede cobrar el respectivo impuesto sobre los ingresos obtenidos en su jurisdicción, lo que lleva a que el contribuyente para determinar la base gravable deba restar del total los ingresos, los ingresos obtenidos o generados en otros municipios. 
en el lugar donde se perfeccione la venta o en el lugar donde se despacha la mercancía o se preste el servicio.

Debido a los altos porcentajes de crecimiento en los ingresos tributarios por Impuesto de Industria y Comercio que se denotan en los párrafos anteriores y en la tabla 4, es menester realizar un análisis de los ingresos suprimiéndole el efecto de la inflación, para así determinar cuál sería su ingreso real sin tener en cuenta los efectos del mercado.

A continuación, se muestran los ingresos tributarios por industria y comercio en el Municipio de Guarne con su respectiva deflactación ${ }^{20}$; es importante aclarar que no siempre el incremento en los ingresos se da por el aumento en los precios de mercado o en la productividad de un negocio, sino que este puede ser producto de los índices económicos del país, como es la inflación.

\section{Tabla 5. Deflactación de ingresos POR Impuesto de Industria y Comercio} en el Municipio de Guarne para los años 2008-2017

\begin{tabular}{|l|c|c|c|c|c|c|c|c|c|c|}
\hline \multicolumn{1}{|c|}{ Vigencia } & $\mathbf{2 0 0 8}$ & $\mathbf{2 0 0 9}$ & $\mathbf{2 0 1 0}$ & $\mathbf{2 0 1 1}$ & $\mathbf{2 0 1 2}$ & $\mathbf{2 0 1 3}$ & $\mathbf{2 0 1 4}$ & $\mathbf{2 0 1 5}$ & $\mathbf{2 0 1 6}$ & $\mathbf{2 0 1 7}$ \\
\hline Ingresos ICA a precios corrientes & 1,619 & 1,561 & 2,497 & 2,769 & 3,021 & 4,305 & 4,676 & 6,778 & 7,348 & 11,507 \\
\hline Variación \% ingresos ICA & 0 & $-3.56 \%$ & $59.99 \%$ & $10.87 \%$ & $91.10 \%$ & $42.50 \%$ & $8.63 \%$ & $44.95 \%$ & $8.42 \%$ & $56.60 \%$ \\
\hline IPC & 1 & 1.02 & 1.05 & 1.09 & 1.12 & 1.14 & 1.18 & 1.26 & 1.33 & 1.39 \\
\hline Tasas anuales de inflación & $7.67 \%$ & $2.00 \%$ & $3.17 \%$ & $3.73 \%$ & $2.44 \%$ & $1.94 \%$ & $3.66 \%$ & $6.77 \%$ & $5.75 \%$ & $4.09 \%$ \\
\hline Deflactación & 1,619 & 1,530 & 2,373 & 2,537 & 2,702 & 3,776 & 3,957 & 5,372 & 5,508 & 8,286 \\
\hline Inflactación & 1,619 & 1,651 & 1,610 & 2,591 & 2,836 & 3,080 & 4,462 & 4,993 & 7,168 & 7,649 \\
\hline Ganancia Monetaria & 0 & 0 & 886.9 & 178.0 & 184.5 & $1,225.0$ & 214.0 & $1,785.2$ & 181.0 & $3,858.0$ \\
\hline Pérdida Monetaria & 0 & 90.03 & 0 & 0 & 0 & 0 & 0 & 0 & 0 & 0 \\
\hline
\end{tabular}

Fuente: Elaboración propia con base en ingresos tributarios suministrados del cHIP.

En la tabla 5 se puede observar que para el periodo 2009 se generó una pérdida monetaria $\$ 90,034$ producto de la disminución en los ingresos corrientes; para el año 2010 el Impuesto de Industria y Comercio tuvo un incremento en los ingresos corrientes por encima de la inflación del 55,07\%; este incremento se dio por factores diferentes a la inflación y al asentamiento de nuevas empresas, ya que para este periodo disminuyó el número de empresas asentadas en un $22 \%$ con respecto al periodo 2009; para el año 2011, el Impuesto de Industria y Comercio aumentó un $6,88 \%$ por encima de la inflación, lo cual se sustenta en un incremento del número de empresas asentadas del $43 \%$ respecto al año 2010; para el periodo 2012, los ingresos por industria y comercio aumentaron un $6,51 \%$ por encima de la inflación, creciendo así el número de empresas asentadas en un $18 \%$ con respecto al

20 Deflactación: Eliminar de un valor monetario los efectos producidos por los cambios en los precios (inflación o deflación). Por lo tanto, deflactar consiste en convertir una magnitud medida en términos nominales en otra expresada en términos reales. 
periodo 2011; para el año 2013, se registró un aumento del Impuesto de Industria y Comercio del 39,79\%; para el periodo 2014 incrementó el Impuesto de Industria y Comercio en un $4,79 \%$ pero se registró una disminución del $1 \%$ en el asentamiento de empresas; para el año 2015, aumentó en un 35,76\% por encima de la inflación, creciendo también el número de empresas asentadas en un 17\%; para el año 2016, el Impuesto de Industria y Comercio aumentó un 2,52\% y, también se registró una disminución en el número de empresas asentadas del 54\%; para 2017, el Impuesto de Industria y Comercio creció un $50,44 \%$; dicha tendencia se puede observar en la siguiente gráfica.

\section{Figura 2. Gráfica de tendencias correspondiente a deflactación de ingresos}

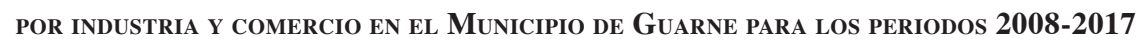

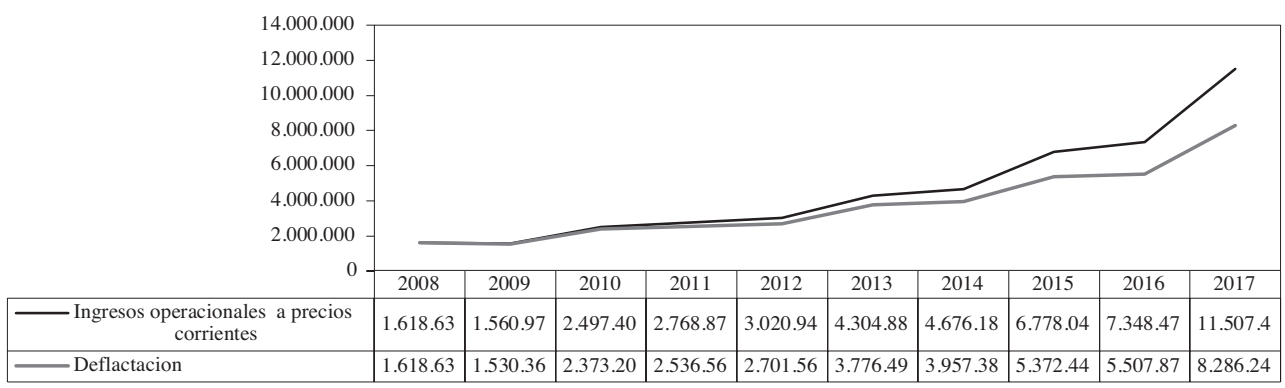

Fuente: Elaboración propia con base en ingresos tributarios suministrados del CHIP.

Otro factor importante que influye en el crecimiento económico del municipio es la fuerza exportadora: según información suministrada por la Cámara de Comercio del Oriente Antioqueño, en el año 2015 el Municipio de Guarne exportaba bienes y servicios a 36 países.

En cuanto a la participación que tiene en la dinámica exportadora de la subregión, el Municipio de Guarne participa con $12,7 \%$ de las exportaciones que se registran en el oriente antioqueño; siendo las empresas de mayor tamaño las más representativas.

Las actividades en las que se viene generando un mayor nivel de exportación son la industria manufacturera, con una participación del 80\%; las actividades de servicios, con un $17 \%$ y el comercio con un 3\% (Municipio de Guarne, 2016, p. 138).

\section{ASENTAMIENTO EMPRESARIAL VS. GENERACIÓN DE EMPLEO DESDE El AÑo 2008 AL 2017 EN EL Municipio DE GuARne}

Como se ha evidenciado en los párrafos anteriores, el Municipio de Guarne en los años objeto de estudio presentó un desarrollo industrial importante y cambios en su estructura tributaría, lo cual incide en diferentes aspectos tales como el punto estratégico de ubicación y los incentivos tributarios; por tal razón, se muestra un panorama del número de empresas nuevas que han abierto establecimiento de comercio desde el año 2008 al 2017. 
Tabla 6. Número de empresas asentadas en el Municipio de Guarne ENTRE LOS AÑOS 2008-2017

\begin{tabular}{|l|c|c|c|}
\hline \multicolumn{1}{|c|}{ Años } & Empresas activas & Variación absoluta & Variación relativa \\
\hline 2008 & 141 & 0 & 0 \\
\hline 2009 & 145 & 4 & $3 \%$ \\
\hline 2010 & 113 & -32 & $-22 \%$ \\
\hline 2011 & 162 & 49 & $43 \%$ \\
\hline 2012 & 191 & 29 & $18 \%$ \\
\hline 2013 & 212 & 21 & $11 \%$ \\
\hline 2014 & 210 & -2 & $-1 \%$ \\
\hline 2015 & 245 & 35 & $17 \%$ \\
\hline 2016 & 112 & -133 & $-54 \%$ \\
\hline 2017 & 179 & 67 & $60 \%$ \\
\hline Total & 1.710 & & \\
\hline
\end{tabular}

Fuente: Elaboración propia con base en información suministrada por Cámara de Comercio del Oriente Antioqueño.

En la tabla anterior se observa que durante el 2008 al 2017 se registraron en la Cámara de Comercio del Oriente Antioqueño 1.710 empresas, de las cuales se evidencian fluctuaciones de un año a otro: observamos que en el año 2016 se presentó una disminución del 54\% respecto al 2015, de la cual pasó de un asentamiento de 245 empresas a 112 empresas, lo cual se debe a que se venía un cambio en el acuerdo municipal, lo cual generó incertidumbre para las empresas, ya que estas esperaban que el nuevo acuerdo tuviera mayores beneficios; por lo tanto, es una de las causas de dicha disminución. Para el año 2017 se impulsó nuevamente el asentamiento de empresas con un crecimiento del $60 \%$ con respecto al año 2016, el cual pasó de 112 empresas a 179 empresas, aumento que se logró gracias al Acuerdo municipal № 07 de 2016, el cual presentó una serie de beneficios económicos, pues se motivó a los inversores, ya que existieron beneficios para las empresas que tuvieran relaciones comerciales con proveedores de la misma jurisdicción, a fin de apoyar la economía local de las organizaciones; también se hicieron muy atractivo los beneficios para quienes contrataran personal discapacitado, quienes vinculen personal mayor de 45 años y quienes apoyen al deporte y la protección animal.

Según datos suministrados por la entidad territorial, es importante resaltar que para el 2016 y 2017 se registraron en la Cámara de Comercio del Oriente Antioqueño 112 y 179 empresas respectivamente. En la figura 3 se puede observar el comportamiento del asentamiento empresarial.

Según estudio realizado de las empresas asentadas en el municipio, el 1,17\% cumple con los requisitos para ser exoneradas del impuesto, ya que de 1.710 empresas registradas en los últimos 10 años, solo 20 empresas han accedido a los beneficios y, de estas, el $70 \%$, equivale a 14 empresas que se encuentran con incentivo tributario vigente y el $30 \%$, es decir las 6 empresas restantes, ya gozaron de dicho beneficio; el bajo porcentaje de las empresas que acceden a estos beneficios continúa siendo principalmente a que "están 
representadas básicamente en el hecho de considerar que los requisitos para acceder a las exenciones son difíciles de cumplir" (Vargas, 2009, p. 113).

Figura 3. Gráfica correspondiente al NúMERo de EMPRESAS Que SE han asentado en el Municipio de Guarne durante los años 2008-2017

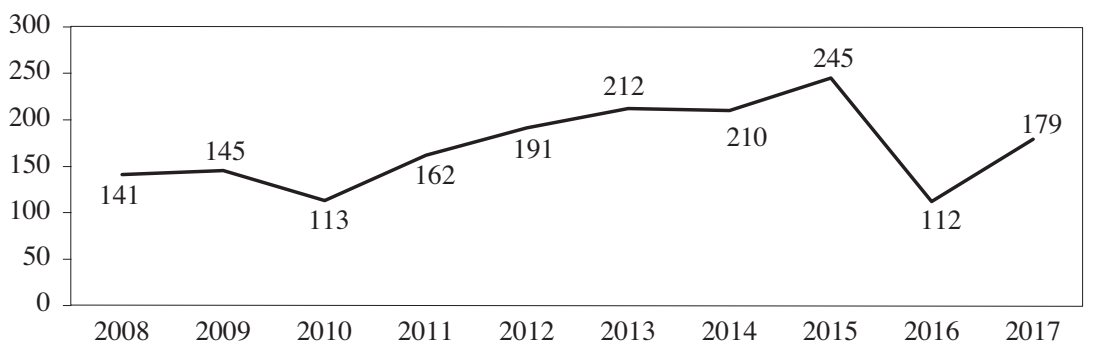

Fuente: Elaboración propia con base en información suministrada por Cámara de Comercio del Oriente Antioqueño.

Otro factor importante que justifica el bajo porcentaje de las empresas que acceden a estos beneficios es el desconocimiento de la normatividad municipal según acercamiento que se tuvo con empresas que se asentaron en los últimos años en el Municipio de Guarne.

A continuación, se presenta una síntesis de los actos administrativos y las empresas que se han beneficiado de las exoneraciones.

Tabla 7. EMpresas exentas en el Municipio de Guarne entre los años 2008-2017

\begin{tabular}{|c|c|c|c|}
\hline Empresa & Beneficio & Acto administrativo & Vigencia \\
\hline Colanta Ltda. & $01 / 01 / 2017$ & $\begin{array}{l}\text { Exenta hasta el mes de junio de } 2020 \text {, según resolución } n^{\circ} \text {. } \\
1666 \text { de diciembre de } 2016 \text {. }\end{array}$ & (4) años. \\
\hline Avon S.A.S & $06 / 05 / 2011$ & $\begin{array}{l}\text { Exenta hasta mayo de 2019, según resolución } n^{\circ} .126 \text { de } \\
\text { julio de } 2011 .\end{array}$ & (10) años. \\
\hline Empacor S.A. & $01 / 03 / 2013$ & $\begin{array}{l}\text { Exenta hasta mayo de } 2019 \text {, según resolución } n^{\circ} .241 \text { de } \\
\text { agosto de } 2013 \text {. Resolución aclaratoria } n^{\circ} .348 \text { de noviem- } \\
\text { bre de } 2014 .\end{array}$ & (10) años. \\
\hline UMO S.A & $01 / 07 / 2014$ & $\begin{array}{l}\text { Exenta hasta junio de } 2018 \text {, según resolución } n^{\circ} .141 \text { de } \\
\text { julio de } 2014 \text {. }\end{array}$ & (4) años. \\
\hline Socoda S.A.S & $01 / 09 / 2014$ & $\begin{array}{l}\text { Exenta hasta agosto de } 2018 \text {, según resolución n. } 257 \text { de } \\
\text { septiembre de } 2014 \text {. }\end{array}$ & (4) años. \\
\hline Polinylon S.A & $01 / 03 / 2015$ & $\begin{array}{l}\text { Exenta hasta febrero de 2019, según resolución n }{ }^{\circ} .043 \text { de } \\
\text { marzo de } 2015 .\end{array}$ & (4) años. \\
\hline Confytex sas & $01 / 03 / 2015$ & $\begin{array}{l}\text { Exenta hasta febrero de } 2019 \text {, según resolución n }{ }^{\circ} .044 \text { de } \\
\text { marzo de } 2015 .\end{array}$ & (4) años. \\
\hline Microdenier S.A. & $01 / 03 / 2015$ & $\begin{array}{l}\text { Exentas hasta febrero de } 2019 ; \text { según resolución nº } .045 \text { de } \\
\text { marzo de } 2015 .\end{array}$ & (4) años. \\
\hline $\begin{array}{l}\text { Aditivos y Quími- } \\
\text { cos S.A. }\end{array}$ & $18 / 03 / 2016$ & $\begin{array}{l}\text { Exenta hasta el mes de marzo de } 2010 \text {, según resolución nº } \\
435 \text { de marzo de } 2016 .\end{array}$ & (4) años. \\
\hline
\end{tabular}




\begin{tabular}{|l|l|l|l|}
\hline \multicolumn{1}{|c|}{ Empresa } & \multicolumn{1}{|c|}{ Beneficio } & \multicolumn{1}{c|}{ Acto administrativo } & \multicolumn{1}{c|}{ Vigencia } \\
\hline Incodi SAS & $14 / 06 / 2016$ & $\begin{array}{l}\text { Exenta hasta el mes de junio de 2020, según resolución } n^{\circ} . \\
\text { 511 de junio de 2016. }\end{array}$ & $(4)$ años. \\
\hline $\begin{array}{l}\text { Aluminum \& Glass } \\
\text { systems SAS }\end{array}$ & $01 / 01 / 2017$ & $\begin{array}{l}\text { Exenta hasta el mes de diciembre de 2020, según resolución } n^{\circ} .1662 \text { de } \\
\text { diciembre de 2016. } \\
(4) \text { años. }\end{array}$ \\
\hline Rotoplast S.A. & $01 / 01 / 2017$ & $\begin{array}{l}\text { Exenta hasta el mes de diciembre de 2020, según resolución } \\
n^{\circ} .1660 \text { de diciembre de 2016. }\end{array}$ & (4) años. \\
\hline Topasa s.A. & $01 / 01 / 2017$ & $\begin{array}{l}\text { Exenta hasta el mes de diciembre de 2020, según resolución } \\
n^{\circ} .1661 \text { de diciembre de 2016. }\end{array}$ & (4) años. \\
\hline Peles s.A.S. & $01 / 12 / 2015$ & $\begin{array}{l}\text { Exenta hasta el mes de noviembre de 2019, según resolución } \\
n^{\circ} .313 \text { de diciembre de 2015. }\end{array}$ & (4) años. \\
\hline
\end{tabular}

Fuente: Elaboración propia con base en información suministrada por Secretaría de Hacienda del Municipio de Guarne.

Por su parte las empresas que fueron exoneradas del Impuesto de Industria y Comercio con el Acuerdo 059 de 2008, durante un periodo de 8 años, las cuales gozaron de beneficios desde el $25 \%$ hasta el $100 \%$ del pago del impuesto, actualmente aportan a la economía del municipio pagando la tarifa plena, y son empresas que aún siguen contribuyendo en la generación de empleo del municipio (Ruiz y Zuluaga, 2018).

La empresa Avon s.A.s. inició sus actividades en el mes de mayo de 2011, con una permanencia de 10 años y cuenta con una exención del 50\% del Impuesto de Industria y Comercio, su beneficio va hasta el mes de mayo de 2019; la empresa Empacor s.A. abrió su establecimiento de comercio en marzo de 2013, con una permanencia de 10 años y actualmente tiene una exención del 75\% del Impuesto de Industria y Comercio, su beneficio va hasta el mes de marzo de 2023. En estos momentos, estas dos empresas contribuyen significativamente a la generación de empleo ya que se acogieron a los requisitos del Acuerdo 059 de 2008.

Los beneficios creados bajo el Acuerdo 004 de 2013 están condicionados a un periodo de 4 años, en el que las empresas no tienen una actividad económica especial: rige bajo las condiciones de nuevas empresas, la empresa UMO s.A. se asentó en julio de 2014, con 4 años de permanencia en la jurisdicción, tuvo exención del 50\% del impuesto hasta junio de 2018; la empresa Socoda S.A.S. se asentó en septiembre de 2014, con 4 años de permanencia y está exenta del 50\% del impuesto, su beneficio va hasta agosto de 2018; las empresas Polinylon s.A., Confytex s.A.S. y Microdenier S.A. fueron beneficiadas en marzo de 2015, ambas tienen 4 años de permanencia y gozan de un beneficio del $100 \%$ del impuesto hasta febrero de 2019; la empresa Peles s.A. se asentó en diciembre de 2015, con 4 años de permanencia en la jurisdicción y cuenta con beneficio del 100\% hasta noviembre de 2019: la empresa Aditivos y Químicos s.A. se asentó en marzo de 2016, actualmente con 4 años de permanencia en la jurisdicción, está exenta del 100\% del impuesto hasta marzo de 2020; la empresa Incodi s.A.S. se asentó en junio de 2016 y actualmente lleva 4 años de permanencia y se encuentra exenta del 100\% del impuesto hasta junio de 2020 . Dichos beneficios traen una serie de costos fiscales, ya que afectan el nivel de recaudo del municipio. 
Finalmente, las empresas Colanta Ltda, Aluminum \& Glass Systems s.A.s, Rotoplast S.A y Topasa S.A fueron beneficiadas en el mes de enero de 2017 a través del Acuerdo 07 de 2016, y están exoneradas del 100\% del pago del Impuesto de Industria y Comercio y, en consecuencia, se acogen a los beneficios de nuevas empresas y su beneficios van hasta diciembre de 2020.

Por último, es importante destacar el impacto que ha tenido la tasa de desempleo del Municipio de Guarne a causa del asentamiento de nuevas empresas, por lo cual se muestra una serie de indicadores del mercado laboral realizando una comparación entre los años 2012 y 2017.

TABLA 8. INDICADORES DEL MERCADO LABORAL ENTRE LOS AÑOS 2012 Y 2017

\begin{tabular}{|l|c|c|c|}
\hline \multicolumn{1}{|c|}{ Indicadores del mercado laboral } & $\mathbf{2 0 1 2}$ & $\mathbf{2 0 1 7}$ & Variación relativa \\
\hline Población total & 45.253 & 48.659 & $7,53 \%$ \\
\hline Población en edad de trabajar & 33.487 & 33.522 & $0,10 \%$ \\
\hline Población económicamente activa & 19.006 & 13.186 & $-30,62 \%$ \\
\hline Tasa global de participación & $56,00 \%$ & $39,33 \%$ & $-29,77 \%$ \\
\hline Población ocupada & 16.155 & 11.222 & $-30,54 \%$ \\
\hline Población desocupada & 2.850 & 1.964 & $-31,09 \%$ \\
\hline Tasa de desempleo & $15,00 \%$ & $14,89 \%$ & \\
\hline
\end{tabular}

Fuente: Información suministrada por la Secretaría de Planeación del Municipio de Guarne.

El municipio ha tenido tasas de desempleo que oscilan entre el $14 \%$ y $15 \%$ en el cual se evidencia un alivio en el mercado laboral: para el año 2017 se registró una tasa de desempleo del 14,89\%, comparada con el año 2012, el cual registró una tasa de desempleo del $15 \%$, se evidencia mejoría en la tasa ya que la población económicamente activa ( $\left.\mathrm{PEA}^{21}\right)$ del año 2012 fue mayor, cuando se registraron 19.006 personas y para el periodo 2017 con 13.186 personas y el número de personas desocupadas para el 2012 era 2.850 y para el $2017,1.964$.

En consideración a lo anterior, se denota que el asentamiento de empresas ha beneficiado a la población y ha generado bienestar en el Municipio de Guarne, debido a que los beneficios fiscales van en sintonía con este proceso de contratación laboral.

\section{CONCLUSIÓN FRENTE A LOS BENEFICIOS TRIBUTARIOS otorgados en el Municipio de Guarne}

En este contexto, las exenciones tributarias creadas por el Municipio de Guarne por medio de los acuerdos municipales de los años objeto de estudio, no han tenido incidencia 
significativa dentro de la estructura tributaria del municipio, ya que solo el 1,17\%, equivalentes a 20 empresas beneficiadas, de las 1.710 empresas que se han asentado entre los años 2008-2017; debido a que muchas empresas son asentadas, pero pocas cumplen con los requisitos de generación de empleo.

Según el análisis efectuado, las empresas asentadas en el Municipio de Guarne no acceden a los beneficios tributarios por desconocimiento de la norma, por lo que se recomienda al municipio difundir por diferentes medios de comunicación los beneficios que tienen contemplados en el acuerdo vigente para las nuevas empresas que se asienten en su jurisdicción, lo cual puede ser una estrategia para impulsar el desarrollo económico del municipio.

La estructura tributaria del municipio ha tenido variaciones positivas en los últimos años en los ingresos de industria y comercio y su complementario: se denota que estos han crecido no producto de la inflación, sino que han sido otros factores los que han incidido en dicho crecimiento, tales como la ubicación estratégica sobre la autopista Medellín-Bogotá , la cercanía a municipios del Valle de Aburrá y al aeropuerto José María lo cual atrae inversión privada, además por su participación en la dinámica exportadora la convierte en la cuarta jurisdicción del Oriente antioqueño que más aporta al PIB subregional.

El municipio ha tenido buenos resultados económicos, ya que el indicador de pagos está por encima del 70\%, ocupando el puesto 121 entre 1.101 municipios y el cuarto lugar a nivel departamental; este indicador demuestra que la rotación en el recaudo de la cartera del municipio ha aumentado significativamente (Herrera, 2018).

Dentro de la estructura tributaria del municipio no se encuentra clasificado el rubro de ingresos por industria y comercio por actividades económicas, lo cual imposibilita determinar el sector económico que más aporta a la economía local y, en efecto, el sector que necesita el impulso mediante incentivos tributarios; a propósito de los nuevos cambios realizados con el Acuerdo municipal 07 de 2016, se recomienda al municipio realizar la clasificación de los ingresos por el Impuesto de Industria y Comercio con el fin de tener mayor trazabilidad en información del sector que más le aporta al municipio.

En consideración a lo preceptuado en la Ley 819 de 2003, el Municipio de Guarne se encuentra en la obligación de informar los costos fiscales en los que ha incurrido en la vigencia; no obstante, la entidad territorial no efectúa un estudio previo que permita determinar su impacto fiscal, limitándose a describir los conceptos de costo fiscal con estimaciones meramente informativas, lo que imposibilita determinar la incidencia de los beneficios fiscales en los ingresos.

De igual forma, la inobservancia de la Ley 819 de 2003 por parte de la entidad territorial en lo que respecta a la adecuada medición del costo tributario, puede tener efectos negativos para la estructura tributaria; distorsionando de esta manera la gestión, control y recaudo del tributo; propiciando la regresividad del sistema y estimulando la elusión y evasión tributaria, generando beneficios a unos cuantos sectores de la economía e incrementando tarifas a los demás. 


\section{Exenciones y beneficios tributarios Municipio de Rionegro}

A continuación se efectúa el análisis de los beneficios tributarios en ICA en el Municipio de Rionegro, en consideración al contenido de los acuerdos que reglamentan beneficios tributarios vigentes desde el año 2008 al 2017; para tal fin, se hizo una revisión inicial por medios electrónicos a efectos de rastrear los acuerdos municipales que permiten acceder a beneficios fiscales propiciados en el marco del asentamiento empresarial, los efectos en el recaudo tributario y el mercado laboral.

\section{AnÁlisis de LAS eXenciones del ACUeRdo MUNICIPAL 029 de 2005}

Para empezar, es importante dar una mirada al Acuerdo municipal 029 de abril 28 de 2005, por el cual se implementa el fomento económico de inversión y desarrollo del Municipio de Rionegro, toda vez que el mismo se convierte en el antecedente normativo más importante en el municipio, para acceder a apoyos y estímulos tributarios; además, porque en el mismo se consagran una serie de acciones que debe implementar la administración municipal para dar cumplimiento al objeto del acuerdo, enmarcado en impulsar el desarrollo económico en el municipio, a través del establecimiento de políticas que estimulen la inversión y el empleo, favoreciendo la consolidación de la alianza estratégica entre el Gobierno y los sectores privado y social.

El artículo 17 del Acuerdo bajo análisis establece, en los siguientes términos, los requisitos que deben cumplir las empresas para ser beneficiarias de los estímulos fiscales, así:

Las personas naturales o jurídicas que deseen recibir los estímulos fiscales de que trata este Acuerdo deberán encontrarse a paz y salvo por todo concepto con el municipio, no haber incurrido en mora de ningún periodo de pago de los tributos objeto de las exenciones durante el tiempo de su beneficio y presentar solicitud por cuadruplicado que contenga la declaración bajo protesta de decir verdad y sujetas a comprobación cuando se estime necesario, de los siguientes documentos y datos:

I. Nombre y domicilio de la empresa solicitante acompañada de copia certificada del testimonio de la escritura constitutiva inscrita ante el Registro Público de Propiedad.

II. Capital por invertir.

III. Localización de la planta y sus oficinas.

IV. Artículos o servicios que producirá y/o prestará.

V. Cantidad y tipo de maquinaria que utilizará. Si con posterioridad se aumentara o substituyera la maquinaria inicialmente instalada, deberá darse aviso a la Secretaría dentro de un término de 8 días siguientes al que concluyan los trabajos respectivos.

VI. Número aproximado de empleados y obreros que se propongan ocupar. 
VII. Fecha aproximada de la apertura y funcionamiento de la nueva industria.

VIII. Estimación de producción anual.

IX. Proyectos, presupuesto y planos de construcciones debidamente aprobados por las autoridades correspondientes, $\mathrm{y}$

X. Las demás formalidades que se soliciten siempre y cuando se relacionen con el objeto de la solicitud.

A la solicitud que se envíe acompañarán los comprobantes que sean necesarios para tal efecto (Acuerdo 029 de 2005).

En el Título sexto se consagran una serie de apoyos y estímulos fiscales, que buscan favorecer la instalación de empresas rionegreras y permitir al municipio ser más competitivo.

El artículo 49 establece que el municipio implementará apoyos a proyectos relacionados con el desarrollo de corredores y parques industriales, así:

... Las empresas que se instalen dentro de parques industriales, recibirán un tratamiento preferencial se harán acreedores a los estímulos previstos en el presente acuerdo.

Las empresas operadoras de parques industriales que realicen esfuerzos de promoción de inversiones en Rionegro, contarán con apoyo hasta un 30\% del costo de montaje de espacios de exhibición en ferias y eventos regionales, departamentales y municipales (Acuerdo 029 de 2005).

Vale la pena anotar que en el acuerdo municipal se consagran una serie de apoyos para las empresas, pero al consultar a la Secretaría de Hacienda Municipal, se informó que algunos de los apoyos consagrados en la norma no se están aplicando en la actualidad; sin embargo, se reiteró por parte de la Administración la importancia del acuerdo para el sector empresarial, dada la aplicabilidad de los estímulos fiscales allí establecidos.

Con respecto a los estímulos fiscales, establece el acuerdo que los mismos tienen por objeto incentivar y facilitar el desarrollo de las actividades sujetas al fomento económico para lograr la generación de empleo, incrementar la inversión productiva y mejorar la competitividad de las empresas rionegreras.

El artículo 64 se refiere a los estímulos fiscales otorgados a los inversionistas; en efecto, se establecen los siguientes esquemas de reducción del pago de impuestos y derechos.

Las empresas que no hagan ningún tipo de expansión locativa y generen nuevos empleos tendrán derecho a las exenciones del Impuesto de Industria y Comercio sobre el mayor crecimiento con respecto al incremento del salario mínimo legal vigente comparados los dos últimos periodos de la respectiva declaración, como se muestra en la Tabla 9. 
Tabla 9. Exención tributaria en el IMpuesto de Industria y Comercio para nuevas empresas asentadas en el Municipio de Rionegro Acuerdo 029 de 2005

\begin{tabular}{|l|c|c|c|}
\hline \multicolumn{1}{|c|}{ Tamaño } & Crecimiento s.M.L.M.v. & \% Exención & $\mathbf{n}^{\circ}$. de empleos nuevos \\
\hline Microempresa & 250 & 50 & 10 \\
\hline Pequeña empresa & 2.500 & 50 & 50 \\
\hline Mediana empresa & 15.000 & 50 & 200 \\
\hline Grande empresa & 30.000 & 50 & 500 \\
\hline
\end{tabular}

Fuente: Acuerdo municipal de Rionegro 029 de 2005.

Según la anterior tabla, a la empresa que no alcance a generar el número de empleos nuevos y el crecimiento de ingresos se le reconocerá la exención proporcional ponderada al número de nuevos empleos generados y al crecimiento de la declaración por encima del incremento del salario mínimo legal mensual vigente.

Así mismo, se precisa que las exenciones solo tendrán una vigencia para cada empresa por un periodo de 5 años y que las empresas que vinculen personas con discapacidad física para efectos de las exenciones se computarán por dos.

De la misma manera, es necesario considerar que en el Acuerdo municipal 029 de 2005, se establecen las circunstancias que conllevan a la extinción y cancelación de los estímulos fiscales, así como el procedimiento que se debe adelantar para ello.

\section{AnÁlisis de las EXENCIONES DEL ACUERdo MUNICIPAL 063 DE 2012}

Otras disposiciones de interés para las empresas, las encontramos establecidas en el Acuerdo municipal 063 de mayo 30 de 2011, "Por el cual se conceden beneficios tributarios para la consolidación de un sector aeronáutico, productivo y estratégico en la localidad", el cual tiene por objeto "implementar las ventajas comparativas y competitivas en la creación y formación de nuevas empresas y filiales o sucursales del sector aeronáutico productivo y estratégico en la jurisdicción para la generación de nuevos empleos a partir de su entrada en vigencia".

Establece el artículo 3 que "corresponde al sector Aeronáutico, estratégico, las empresas dedicadas a la prestación de servicios de transporte aéreo, transporte de pasajeros o de carga".

Por su parte, el artículo 5 establece:

Las empresas del sector Aeronáutico, productivo y estratégico que radiquen sus centros de operaciones en el Municipio de Rionegro a la entrada en vigencia del presente Acuerdo y generen nuevos empleos a los habitantes de Rionegro con no menos de cinco años de antigüedad, conforme a su tamaño, tendrán un beneficio tributario del $100 \%$ del Impuesto de Industria y Comercio por un periodo de 10 años. 
Parágrafo: En caso de no generar el número empleos permanentes acorde al tamaño a su tamaño de empresa conforme a las normas que regulan la materia, el beneficio tributario será proporcional al número de empleos nuevos.

El parágrafo del artículo 6 establece: "Las personas que se vinculen con discapacidad severa, se computarán por dos empleos nuevos, siempre y cuando sean permanentes”.

Con respecto a la pérdida del beneficio tributario, establece el artículo 7 lo siguiente:

Cualquiera sea su naturaleza jurídica y tamaño de empresa que ha incurrido en mora de sus obligaciones tributarias con el municipio, o haya presentado información que no corresponda a los empleos nuevos generados en cada vigencia fiscal, perderá el beneficio tributario por todo el periodo (Acuerdo 063, 2012).

\section{ANÁLISIS DE LAS EXENCIONES ACUERdo MUNICIPAL 009 DE 2014}

Para finalizar, es importante mencionar que el Acuerdo municipal 009 de julio 29 de 2014, "Por el cual se conceden beneficios tributarios temporales para el fomento de la inversión en el Municipio de Rionegro", consagra una serie de beneficios tributarios a título de exenciones temporales para aquellas nuevas empresas que construyan su sede fabril o establecimiento de comercio en la localidad, dedicadas a actividades industriales, comerciales o de servicios, que se asentaren en el Municipio de Rionegro, a partir de la entrada en vigencia del acuerdo hasta el 31 de diciembre de 2015.

\section{ANÁLISIS DEL RECAUdO DE INDUSTRIA Y COMERCIO 2008 AL 2017 EN EL Municipio RioneGro}

Mediante el desarrollo del objeto de estudio y la información suministrada por la entidad, se evidencia que el Municipio de Rionegro en la estructura de sus estados financieros tiene clasificados sus ingresos fiscales en tributarios y no tributarios; sin embargo, dentro de la suscitada estructura no se tiene clasificado el rubro de los ingresos por Impuesto de Industria y Comercio, y por esta razón se proyecta la información de acuerdo con los datos registrados por el cHIP; esto se debe a que la información suministrada a esta plataforma sí cuenta con la discriminación de cada uno de los rubros que componen los ingresos del municipio, donde se puede discriminar el rubro correspondiente al Impuesto de Industria y Comercio.

Es así como a continuación se muestran los ingresos obtenidos por el rubro de Impuesto de Industria y Comercio a precios corrientes para el Municipio de Rionegro en el periodo comprendido desde el 2008 y el 2017. 
TABla 10. Ingresos tributarios de IndUSTRIA y CoMercio

A PRECIOS CORRIENTES PERIODO 2008-2017

\begin{tabular}{|l|c|c|c|}
\hline \multicolumn{1}{|c|}{ Periodo } & Ingreso -Industria y Comercio & Variación absoluta & Variación relativa \\
\hline 2008 & 16.626 .000 & 0 & $0 \%$ \\
\hline 2009 & 17.434 .000 & 808.000 & $5 \%$ \\
\hline 2010 & 18.425 .000 & 991.000 & $5 \%$ \\
\hline 2011 & 20.225 .000 & 1.800 .000 & $9 \%$ \\
\hline 2012 & 23.171 .000 & 2.946 .000 & $13 \%$ \\
\hline 2013 & 30.289 .000 & 7.118 .000 & $24 \%$ \\
\hline 2014 & 36.617 .000 & 6.328 .000 & $17 \%$ \\
\hline 2015 & 41.605 .000 & 4.988 .000 & $12 \%$ \\
\hline 2016 & 48.770 .000 & 7.165 .000 & $15 \%$ \\
\hline 2017 & 57.412 .000 & 8.642 .000 & $15 \%$ \\
\hline
\end{tabular}

Fuente: Elaboración propia con base en información tomada del cHIP.

En la tabla 10 se pueden visualizar los ingresos tributarios por concepto industria y comercio del municipio durante los periodos 2008-2013, periodo en el cual tiene vigencia el Acuerdo 029 del 2005, el cual contempla exenciones hasta por cinco años y está condicionado de la siguiente manera:

Las empresas que generen nuevos empleos tendrán derecho a las exenciones del Impuesto de Industria y Comercio sobre el mayor crecimiento con respecto al incremento del salario mínimo legal vigente comparados los dos últimos periodos de la respectiva declaración de la siguiente forma: las exenciones serán del 50\% siempre y cuando las microempresas generen 10 nuevos empleos, la pequeña empresa 50 nuevos empleos, mediana empresa, 200 nuevos empleos y gran empresa, 500 nuevos empleos.

A las empresas que no alcancen a generar el número de empleos nuevos y el crecimiento de ingresos, se les reconocerá la exención proporcional ponderada al número de nuevos empleos generados y al crecimiento de la declaración por encima del incremento del salario mínimo legal mensual vigente, de conformidad con el contenido del acuerdo municipal.

En este mismo sentido, los ingresos por concepto de Impuesto de Industria y Comercio durante los años 2008-2013 muestran una tendencia creciente. De esta manera, para los años 2008- 2009 se registró un crecimiento significativo en el Impuesto de Industria y Comercio con una variación absoluta del 5\%; entre los años 2009-2010 creció un 5\%; para los años 2010-2011, un 9\% y, por último, entre el año 2012 y 2013 creció un 24\% en industria y comercio.

No obstante, el Acuerdo 063 de 2012 concede beneficios tributarios para la consolidación de un sector aeronáutico, productivo y estratégico en la localidad de Rionegro con no 
menos de cinco años de antigüedad, y conforme a su tamaño, tendrán un beneficio tributario del 100\% del Impuesto de Industria y Comercio por un periodo de 10 años.

En caso de no generar el número de empleos permanentes acorde con el tamaño de empresa conforme a las normas que regulan la materia, el beneficio tributario será proporcional al número de empleos nuevos; así mismo establece que "las personas que se vinculen con discapacidad severa, se computarán por dos empleos nuevos, siempre y cuando sean permanentes" (Acuerdo 063 de 2012).

Para los periodos 2014-2017, en vigencia del Acuerdo municipal 009 de julio 29 de 2014 el cual concede beneficios tributarios temporales para el fomento de la inversión en el Municipio de Rionegro, se consagra una serie de beneficios tributarios a título de exenciones temporales para aquellas nuevas empresas que construyan su sede fabril o establecimiento de comercio en la localidad; dedicadas a actividades industriales, comerciales o de servicios, que se asentaren en el Municipio de Rionegro, a partir de la entrada en vigencia del acuerdo hasta el 31 de diciembre de 2015.

Para el último año objeto de estudio 2017, tuvo un crecimiento constante, manteniendo el porcentaje de crecimiento del año anterior en los ingresos tributarios, por concepto de Impuesto de Industria y Comercio; en este contexto se hace importante realizar un análisis de los ingresos suprimiendo el efecto de la inflación, para así determinar cuál sería su ingreso real sin tener en cuenta los efectos del mercado.

TABLA 11. Deflactación de INGResos POR IMPUESTo de INDUSTRIA

y Comercio en el Municipio de Rionegro para los años 2008-2017

\begin{tabular}{|l|c|c|c|c|c|c|c|c|c|c|}
\hline \multicolumn{1}{|c|}{ Vigencia } & $\mathbf{2 0 0 8}$ & $\mathbf{2 0 0 9}$ & $\mathbf{2 0 1 0}$ & $\mathbf{2 0 1 1}$ & $\mathbf{2 0 1 2}$ & $\mathbf{2 0 1 3}$ & $\mathbf{2 0 1 4}$ & $\mathbf{2 0 1 5}$ & $\mathbf{2 0 1 6}$ & $\mathbf{2 0 1 7}$ \\
\hline $\begin{array}{l}\text { Ingresos ICA } \\
\text { a precios } \\
\text { corrientes }\end{array}$ & 16,626 & 17,434 & 18,425 & 20,225 & 23,171 & 30,289 & 36,617 & 41,605 & 48,770 & 57,412 \\
\hline $\begin{array}{l}\text { Variación \% } \\
\text { ingresos ICA }\end{array}$ & 0 & $4,86 \%$ & $5,68 \%$ & $9,77 \%$ & $14,57 \%$ & $30,72 \%$ & $20,89 \%$ & $13,62 \%$ & $17,22 \%$ & $17,72 \%$ \\
\hline IPC & 1 & 1.02 & 1.05 & 1.09 & 1.12 & 1.14 & 1.18 & 1.26 & 1.33 & 1.39 \\
\hline $\begin{array}{l}\text { Tasas anuales } \\
\text { de inflación }\end{array}$ & $7,67 \%$ & $2,00 \%$ & $3,17 \%$ & $3,73 \%$ & $2,44 \%$ & $1,94 \%$ & $3,66 \%$ & $6,77 \%$ & $5,75 \%$ & $4,09 \%$ \\
\hline Deflactación & 16,626 & 17,092 & 17,548 & 18,555 & 20,688 & 26,569 & 31,031 & 33,020 & 36,669 & 41,304 \\
\hline Inflactación & 16,626 & 16,959 & 17,987 & 19,112 & 20,718 & 23,621 & 31,598 & 39,096 & 43,997 & 50,765 \\
\hline $\begin{array}{l}\text { Ganancia } \\
\text { Monetaria }\end{array}$ & 0 & 4,754 & 4,383 & 1,113 & 2,453 & 6,668 & 5,219 & 2,509 & 4,773 & 6,647 \\
\hline $\begin{array}{l}\text { Pérdida } \\
\text { Monetaria }\end{array}$ & 0 & 0 & 0 & 0 & 0 & 0 & 0 & 0 & 0 & 0 \\
\hline
\end{tabular}

Fuente: Elaboración propia con base en ingresos tributarios suministrados en el cHIP. 
En la anterior tabla se pueden observar los ingresos tributarios por industria y comercio con su respectiva deflactación ${ }^{22}$; es importante resaltar que no siempre el incremento en los ingresos se da por el aumento en los precios de mercado o en la productividad de un negocio, sino que este puede ser producto de los índices económicos del país, como es la inflación.

En la siguiente grafica se muestra las tendencias correspondiente a deflactación de ingresos por industria y comercio en el Municipio de Rionegro para los periodos 2008-2017.

Figura 4. Tendencias Correspondiente a deflactación de ingresos

por industria y comercio en el Municipio de Rionegro para los periodos 2008-2017

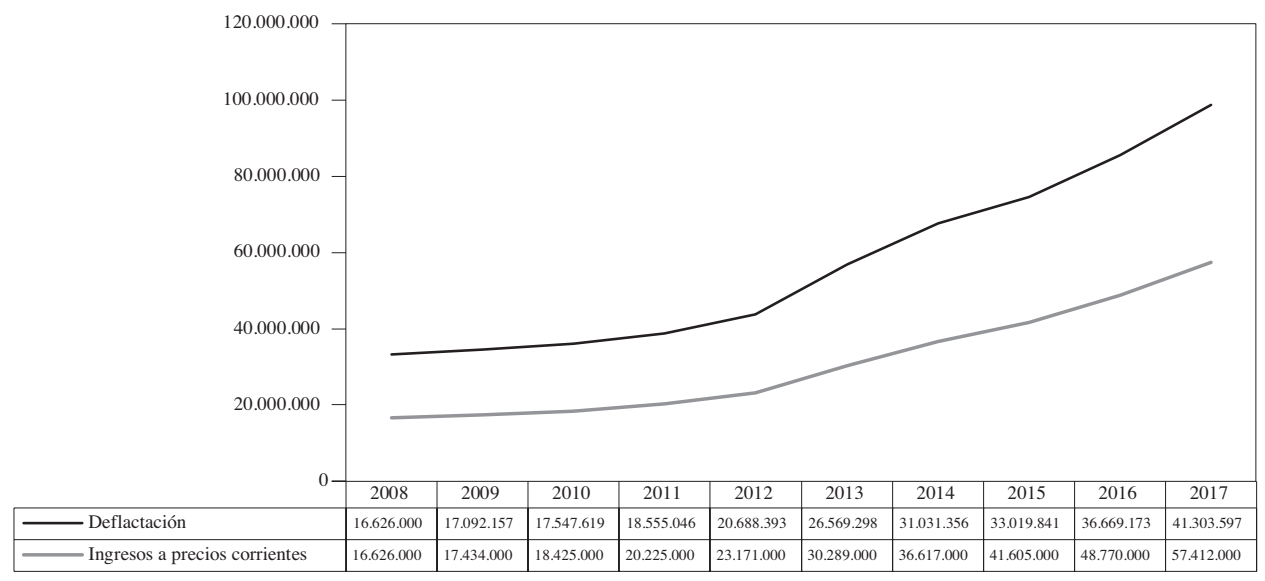

Fuente: Elaboración propia con base en ingresos tributarios suministrados del cHIP.

\section{ASENTAMIENTO EMPRESARIAL VS. GENERACIÓN}

DE EMPLeO DESDE EL 2008 al 2017 en el MuniciPio de Rionegro

Como se ha precisado en los párrafos anteriores, el Municipio de Rionegro en el periodo objeto de estudio ha presentado un desarrollo industrial importante y cambios en su estructura tributaria, lo cual incide en diferentes aspectos, tales como el punto estratégico de ubicación; por tal razón, en la siguiente tabla se muestra un panorama del número de empresas nuevas que han abierto establecimiento de comercio desde el año 2008 al 2017.

22 Deflactación: Eliminar de un valor monetario los efectos producidos por los cambios en los precios (inflación o deflación). Por lo tanto, deflactar consiste en convertir una magnitud medida en términos nominales en otra expresada en términos reales. 
Tabla 12. Número de empresas asentadas en el Municipio de Rionegro ENTRE LOS AÑOS 2008-2017

\begin{tabular}{|l|c|c|c|}
\hline \multicolumn{1}{|c|}{ Años } & Empresas activas & Variación absoluta & Variación relativa \\
\hline 2008 & 6.539 & 0 & 0 \\
\hline 2009 & 6.858 & 319 & $4,65 \%$ \\
\hline 2010 & 7.173 & 315 & $4,39 \%$ \\
\hline 2011 & 7.505 & 332 & $4,42 \%$ \\
\hline 2012 & 7.916 & 411 & $5,19 \%$ \\
\hline 2013 & 7.500 & -416 & $-5,55 \%$ \\
\hline 2014 & 8.323 & 823 & $9,89 \%$ \\
\hline 2015 & 9.473 & 1150 & $12,14 \%$ \\
\hline 2016 & 10.302 & 829 & $8,05 \%$ \\
\hline 2017 & 11.355 & 1053 & $9,27 \%$ \\
\hline Total & 4.816 & & \\
\hline
\end{tabular}

Fuente: Elaboración propia con base en la información suministrada por la Cámara de Comercio del Oriente Antioqueño.

En la tabla anterior, así como en la siguiente gráfica se observa que durante los últimos 10 años se han registrado en la Cámara de Comercio del oriente antioqueño 4.816 empresas en el Municipio de Rionegro, presentándose fluctuaciones de un año a otro: observamos que en el año 2013 se presentó una disminución del 5,55\% respecto al 2012, pasó de un asentamiento de 7.916 empresas a 7.500 empresas; para el año 2014 se impulsó nuevamente el asentamiento de empresas con un crecimiento del 9,14\% con respecto al año 2013, el cual pasó de 7.500 empresas a 8.323 empresas; este aumento se genera debido a la formalización empresarial.

Figura 5. Número de empresas Que Se han asentado

en el Municipio de Rionegro durante los años 2008-2017

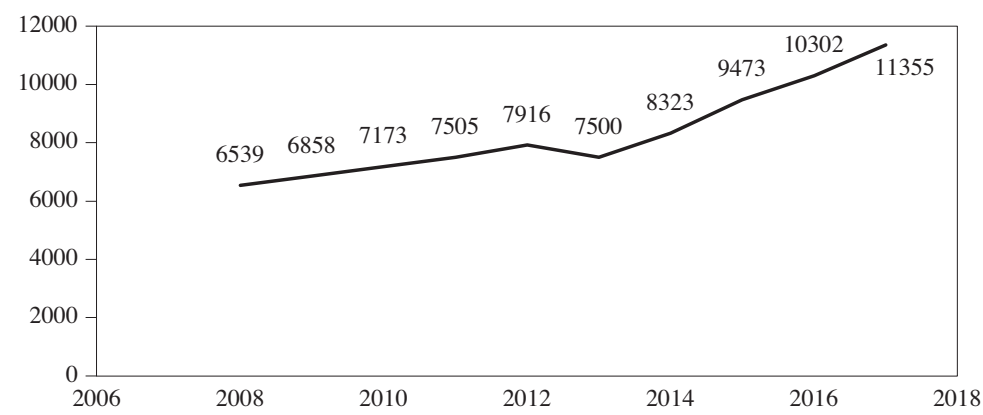

Fuente: Elaboración propia con base con información suministrada por la Cámara de Comercio del Oriente Antioqueño. 
Según estudio realizado de las empresas asentadas en el municipio, el 0,000002\% cumple con los requisitos para ser exoneradas del impuesto, ya que de 4.816 empresas registradas en los últimos 10 años, solo Panamericana de Alimentos s.A.s logró acceder a la exención; inicialmente por 5 años y posteriormente prorrogado conforme al Acuerdo 029 de 2015. Global Rotor s.A.s solicitó pero no cumplía con los requisitos; se evidencia entonces el bajo porcentaje de las empresas que acceden a estos beneficios como consecuencia de la rigurosidad de los requisitos para lograrlos.

\section{TABla 13. EMPRESAS BENEFICIADAS CON BENEFICIOS TRIBUTARIOS en el Municipio de Rionegro entre los años 2008-2017}

\begin{tabular}{|c|l|c|}
\hline Empresa & \multicolumn{1}{|c|}{ Acto administrativo } & \multicolumn{1}{c|}{ Vigencia } \\
\hline Panamericana de Alimentos S.A.S & $\begin{array}{l}\text { Exenta hasta el mes de diciembre de } \\
\text { 2019. Exención desde el 2009-12-02 } \\
\text { conforme al Acuerdo 029/2005. }\end{array}$ & Diez (10) años de exención. \\
\hline
\end{tabular}

Fuente: Elaboración propia con base en información suministrada por la Secretaría de Hacienda del Municipio de Rionegro.

Otro factor importante que justifica el bajo porcentaje de las empresas que acceden a estos beneficios es el desconocimiento de la normatividad municipal.

Finalmente, es importante resaltar el impacto que ha tenido la tasa de desempleo del Municipio de Rionegro a causa del asentamiento de nuevas empresas, por lo cual se muestra una serie de indicadores del mercado laboral realizando una comparación entre los años 2008 y 2017.

TABLA 14. INDICADORES DEL MERCADO LABORAL en el Municipio de Rionegro entre los años 2008 y 2017

\begin{tabular}{|l|c|c|}
\hline \multicolumn{1}{|c|}{ Indicadores del mercado laboral } & $\mathbf{2 0 0 8}$ & $\mathbf{2 0 1 7}$ \\
\hline Población total & 106.404 & 124.219 \\
\hline Población en edad de trabajar & $76 \%$ & $83 \%$ \\
\hline Población económicamente activa & - & - \\
\hline Tasa global de participación & $62,5 \%$ & $79,98 \%$ \\
\hline Población ocupada & $56,4 \%$ & $69,36 \%$ \\
\hline Población desocupada & $39,6 \%$ & $-\%$ \\
\hline Tasa de desempleo & $9,3 \%$ & $13,28 \%$ \\
\hline
\end{tabular}

Fuente: Información suministrada por la Secretaría de Planeación del Municipio de Rionegro.

Según la anterior tabla, el municipio ha tenido tasas de desempleo que oscilan entre $9 \%$ y 14\%, lo cual evidencia una afectación negativa en el mercado laboral: para el año 2017 
se registró una tasa de desempleo del 13,28\% en comparación con el año 2008, el cual registro una tasa de desempleo del 9,3\%; en este sentido no se evidencia mejoría ya que la tasa de desempleo aumento.

De acuerdo con lo anterior, se denota que el asentamiento de empresas no ha beneficiado a la población y, por ende, no ha generado bienestar a la población del Municipio de Rionegro debido a que los beneficios fiscales no van acordes con el proceso de contratación laboral.

\section{CONCLUSIÓN FRENTE A LOS BENEFICIOS TRIBUTARIOS otorgados En El Municipio de Rionegro}

En este contexto, las exenciones tributarias creadas por el Municipio de Rionegro por medio de los acuerdos municipales de los años objeto de estudio no han tenido incidencia significativa dentro de la estructura tributaria del municipio ya que solo el 0,000002\%, equivalente a 1 empresa de las 4.816 empresas que se han asentado entre los años 20082017, se ha acogido a estos beneficios debido a que muchas empresas son creadas, pero pocas cumplen con los requisitos de generación de empleo.

En consecuencia, es significativo el número de empresas asentadas en el Municipio de Rionegro que no acceden a los beneficios tributarios por desconocimiento de la norma o por la rigurosidad de los requisitos para acceder a la exención, por lo que se recomienda al municipio difundir por diferentes medios de comunicación los beneficios que tienen contemplados en el acuerdo vigente para las nuevas empresas que se asienten en su jurisdicción, y efectuar un estudio técnico de los requisitos exigidos, lo cual puede ser una estrategia para impulsar el desarrollo económico del municipio.

La estructura tributaria local ha tenido variaciones positivas en los últimos años en los ingresos de industria y comercio y su complementario: se observa que estos han crecido no producto de la inflación, sino que han sido otros factores los que han incidido a dicho crecimiento, tales como la ubicación estratégica sobre la autopista Medellín-Bogotá, la zona franca, el corredor industrial, la cercanía a municipios del Valle de Aburrá y al aeropuerto José María Córdova, lo cual atrae inversión privada, además por su participación en la dinámica exportadora la convierte en el municipio del Valle de San Nicolás que más aporta al PIB subregional.

El municipio ha tenido buenos resultados en el desempeño fiscal, ya que está por encima del $89 \%$, ocupando el puesto 2 entre 1.101 municipios y el primer lugar entre los 125 municipios a nivel departamental, tal como se muestra en la siguiente gráfica. 
Figura 6: Índice de desempeño fiscal para el Municipio de Rionegro

EN EL PERIODO 2002-2017

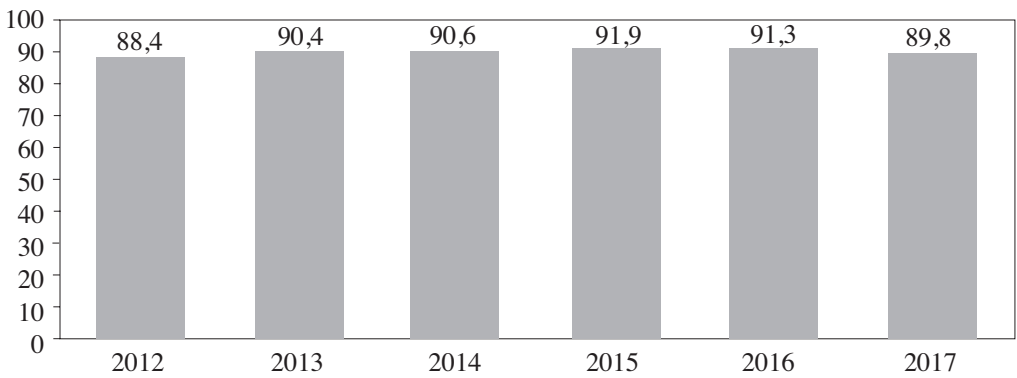

Fuente: DNP Desempeño fiscal año 2012- 2017.

Dentro de la estructura tributaria del municipio no se encuentra clasificado el rubro de ingresos por industria y comercio por actividades económicas, por lo cual es difícil determinar el sector económico que más aporta a la economía del municipio y cuál sector requiere el impulso mediante incentivos tributarios; es así como se recomienda al municipio realizar la clasificación de los ingresos por concepto de Impuesto de Industria y Comercio con el fin de tener mayor trazabilidad en información.

En consideración a lo preceptuado en la Ley 819 de 2003, el Municipio de Rionegro se encuentra en la obligación de informar los costos fiscales en los que ha incurrido en la vigencia; no obstante, la entidad territorial no efectúa un estudio previo que permita determinar su impacto fiscal, limitándose a describir los conceptos de costo fiscal con estimaciones meramente informativas, lo que imposibilita determinar la incidencia de los beneficios fiscales en los ingresos.

De igual forma, la inobservancia de la Ley 819 de 2003 por parte de la entidad territorial en lo que respecta a la adecuada medición del costo tributario, puede tener efectos negativos para la estructura tributaria; se distorsiona de esta manera la gestión, control y recaudo del tributo, propiciando la regresividad del sistema y estimulando la elusión y evasión tributaria, generando beneficios a unos cuantos sectores de la economía e incrementando tarifas a los demás.

\section{Análisis jurídico y económico de los beneficios fiscales}

En el presente acápite se efectúa el análisis de la incidencia de la autonomía territorial en la concesión de exenciones que posibilitan el asentamiento empresarial en los municipios de Guarne y Rionegro, y finalmente se determinan los efectos del asentamiento empresarial en las localidades objeto de estudio. 


\section{A. Análisis autonomía tributaria territorial}

El núcleo esencial de la autonomía territorial se encuentra consagrado en la Constitución Política de Colombia, artículo 287, con respecto a los poderes políticos, administrativos y financieros de los entes territoriales; artículo 300-4, a través del cual se faculta a los entes territoriales para decretar los impuestos necesarios para el cumplimiento de sus fines constitucionales; artículo 313-4, en cuya virtud se establece que les corresponde votar los tributos de conformidad con la Constitución y la ley; artículo 338 en cuya virtud se consagra el poder tributario, aspecto respecto del cual tuvimos ocasión de analizar las diversas líneas jurisprudenciales en la Corte Constitucional y el Consejo de Estado, y, por supuesto, los artículos 294 y 362, que establecen que las rentas de los entes son de su exclusiva propiedad y no pueden ser objeto de exenciones por parte del Congreso de la República.

\section{B. Las exenciones frente a la autonomía tributaria territorial}

De conformidad con los antecedentes consultados, la exenciones otorgadas por las entidades territoriales tienen su fuente legal en el artículo 1 de la Ley 29 de 1963, el cual establece que solo los concejos municipales y el concejo distrital podrán decretar exenciones o exoneraciones de los impuestos o contribuciones que por la Constitución, la ley y las ordenanzas les corresponden; y el artículo 38 de la Ley 14 de 1983, en virtud de la cual se establece el límite de diez años durante el cual un ente territorial puede otorgar exenciones.

Conforme a la jurisprudencia analizada, encontramos que la facultad de establecer exenciones tributarias tiene como límite la ley de autorización, en lo que respecta a no modificar los elementos esenciales del tributo, consagrados por el Congreso de la República, y que dicha facultad responde a los principios que orientan el sistema tributario en Colombia.

El ejercicio del poder tributario desde la perspectiva de establecer exenciones en su territorio responde a una finalidad constitucionalmente admisible, pues es una de las expresiones del principio de autonomía tributaria de los entes territoriales.

La exención necesariamente afecta la realización del hecho generador, y, en consecuencia, modifica, dentro de su jurisdicción, un elemento esencial del tributo.

La potestad tributaria frente a la capacidad de establecer exenciones no vulnera el núcleo esencial de la autonomía territorial, pues, como se indicó, este reducto mínimo indisponible está enmarcado en el texto del artículo 287 constitucional.

Conforme lo anterior, consideramos que el núcleo esencial para establecer exenciones tributarias lo constituye la posibilidad que tiene el Congreso de la República de establecer el hecho generador del tributo, luego en el evento que se intervenga el mismo por la vía de una exención otorgada por concejo municipal o asamblea departamental, necesariamente se afecta un elemento esencial establecido por el legislador, razón por la cual, en palabras de Perdomo (2018), “ante un juicio de ponderación necesariamente debe ceder la facultad 
de los entes locales, ha de tenerse en cuenta que los entes territoriales no ostentan soberanía fiscal en tanto su actuación autónoma encuentra límite en la Ley".

Un beneficio tributario es una herramienta de la política pública que aprueba un tratamiento impositivo diferencial respecto a la norma general para incentivar o estimular diversos aspectos o sectores de la economía, como el ahorro, el desarrollo de un sector específico, la economía solidaria, el mercado accionario, la participación política, la inversión nacional y extranjera, la estabilización económica y la protección social, entre otros.

En consecuencia, la jurisprudencia constitucional ha establecido que la exención tributaria no es un fin para el Estado ni para el sujeto pasivo de la obligación fiscal, sino que se trata de un instrumento de estímulo tributario que puede estar orientado hacia diferentes propósitos, en tanto no puede modificar los elementos esenciales contenidos en la ley de autorización, y por la Constitución, debido a que las exenciones, además de perseguir un fin constitucionalmente admisible, deben corresponder a los principios del Derecho tributario.

Dentro de las facultades que ostentan los entes territoriales en materia de poder tributario, se encuentran aquellas en virtud de las cuales se les faculta para conceder exenciones tributarias en su respectivo territorio. Dicha facultad se deriva de una norma de prohibición contenida en la Constitución y de acuerdo con la cual le es prohibido al Congreso de la República conceder exenciones o tratos preferenciales respecto de los tributos de las entidades territoriales. Adicionalmente, tal prerrogativa encuentra sustento en normas de rango legal a través de las cuales expresamente se indica que son los concejos municipales y asambleas departamentales los facultados para conceder exenciones en su territorio dentro de un límite temporal de 10 años (Perdomo 2018).

El poder tributario de los entes territoriales también encuentra un ámbito de especial aplicación cuando a través de sus órganos de representación popular, municipios, distritos especiales y departamentos, establecen exenciones o beneficios tributarios frente a los supuestos de hecho que, en su criterio, son susceptibles de un trato preferencial, circunstancias estas de política fiscal que terminan enervando la configuración de uno de los elementos esenciales del tributo, el hecho generador.

\section{Efectos del asentamiento empresarial en los municipios objeto de estudio}

El documento presentado por la comisión tripartita ${ }^{23}$ en el año 2012, denota que en el Valle de San Nicolás, la mayor presencia de proyectos inmobiliarios que tienen como destino algún uso económico, se ha venido dando, de manera muy marcada, en el eje de la autopista Medellín-Bogotá a la altura del Municipio de Guarne, así como en los corredores que comunican a este municipio con Rionegro y el aeropuerto internacional. Estos dos

23 Gobernación de Antioquia, Alcaldía de Medellín, Área Metropolitana - Tres Valles: el territorio de la economía. Una estrategia de ordenamiento económico-territorial para los valles de Aburra, Occidente Cercano y San Nicolás en Antioquia. 
municipios son los de mayor proyección actual y potencial para la localización de actividades manufactureras a gran escala (en conjunto, representaron el 17\% del área destinada a estos proyectos en Tres Valles), dinámica que también se está expandiendo con fuerza (aunque con menos intensidad) hacia los municipios de Marinilla y El Santuario (CT, 2012, p. 70).

En este sentido, Blomström (2000), Bolnick (2004) y Gomez Sabaini (2006), citados por Jiménez, Podesta (2009), sostienen que las políticas de incentivos tributarios han sido efectivas únicamente cuando se han establecido en jurisdicciones con cierta estabilidad política, económica, seguridad, mano de obra calificada, buen nivel de infraestructura y con cierta apertura comercial.

De tal modo, las exenciones tributarias creadas por el Municipio de Guarne por medio de los acuerdos municipales de los años objeto de estudio no han tenido incidencia significativa dentro de la estructura tributaria del municipio, ya que solo el 1,17\% equivalentes a 20 empresas de las 1.710 empresas que se han asentado entre los años 2008-2017 se han acogido a estos beneficios debido a que muchas empresas son creadas, pero pocas cumplen con los requisitos de generación de empleo.

En consecuencia, gran parte de las empresas asentadas en el Municipio de Guarne no acceden a los beneficios tributarios por desconocimiento de la norma, por lo que se recomienda al municipio difundir por diferentes medios de comunicación los beneficios que tienen contemplados en el acuerdo vigente para las nuevas empresas que se asienten en su jurisdicción, lo cual puede ser una estrategia para impulsar el desarrollo económico del municipio.

La estructura tributaria del municipio ha tenido variaciones positivas en los últimos años en los ingresos de industria y comercio y su complementario: se denota que estos han crecido no producto de la inflación, sino que han sido otros factores los que han incidido a dicho crecimiento, tales como la ubicación estratégica sobre la autopista Medellín Bogotá, la cercanía a municipios del Valle de Aburrá y al aeropuerto José María Córdova, lo cual atrae inversión privada, además por su participación en la dinámica exportadora la convierte en la cuarta subregión del Oriente antioqueño que más aporta al PIB subregional.

El municipio ha tenido buenos resultados económicos, ya que el indicador de pagos está por encima del 70\%, ocupando el puesto 121 entre 1.101 municipios y el cuarto lugar a nivel departamental; este indicador demuestra que la rotación en el recaudo de la cartera del municipio ha aumentado significativamente (Herrera, 2018).

Por su parte, las exenciones tributarias reglamentadas por el Municipio de Rionegro en los años objeto de estudio no han tenido incidencia significativa dentro de la estructura tributaria del municipio, ya que solo el $0,000002 \%$, equivalente a 1 empresa beneficiada de las 4.816 empresas asentadas entre los años 2008-2017, debido a que muchas empresas son creadas, pero pocas cumplen con los requisitos de generación de empleo.

En consideración a los apartes precedentes, se recomienda al municipio difundir por diferentes medios de comunicación los beneficios que tienen contemplados en el acuerdo vigente para las nuevas empresas que se asienten en su jurisdicción; así mismo, efectuar 
un estudio técnico de los requisitos exigidos, lo cual puede ser una estrategia para impulsar el desarrollo económico local.

De otra parte, la estructura tributaria del Municipio de Rionegro ha tenido variaciones positivas en los últimos años en los ingresos de industria y comercio y su complementario, en tanto se se denota que estos han crecido no producto de la inflación, sino que han sido otros factores los que han incidido a dicho crecimiento, tales como la ubicación estratégica sobre la autopista Medellín-Bogotá, la zona franca, el corredor industrial, la cercanía a municipios del Valle de Aburrá y al aeropuerto José María Córdova, lo cual atrae inversión privada, además por su participación en la dinámica exportadora la convierte en el municipio del Valle de San Nicolás que más aporta al PIB subregional.

No obstante, se recomienda que las entidades territoriales objeto de estudio ajusten los mecanismos subjetivos desgravatorios, en el sentido de armonizar y simplificar en la reglamentación, los requisitos para acceder a los beneficios tributarios.

\section{Conclusiones}

Los efectos generados para las entidades territoriales son considerados de vital importancia en la política fiscal; de hecho, se hace necesario realizar su evaluación y seguimiento. Así, frente a los beneficios tributarios otorgados por las entidades territoriales en el marco del principio de autonomía territorial, se concluye:

Los beneficios tributarios otorgados por las entidades territoriales en el marco de la autonomía territorial son considerados como instrumentos para incentivar el desarrollo económico y social de las jurisdicciones; no obstante, en consideración al artículo 38 de la Ley 14 de 1983, el establecimiento de los beneficios tributarios por parte de las entidades territoriales estará limitado por el termino de diez años, tiempo en el cual un ente territorial podrá otorgar exenciones.

Respecto a las exenciones, en los municipios objeto de estudio se han configurado como un instrumento político para los gobiernos de turno; toda vez que en los municipios del Valle de San Nicolás se propicia la competencia tributaria al establecer exenciones, tanto así que los municipios objeto de estudio en la actualidad están gestionando un nuevo acuerdo de beneficios tributarios ante la competencia con otras jurisdicciones.

Una vez efectuado el análisis de la información suministrada por las entidades objeto de estudio, es posible inferir que la concesión de exenciones no tiene un impacto significativo en el rubro de ingresos; no obstante, se destaca el comportamiento positivo en el mercado laboral como consecuencia del asentamiento en las jurisdicciones de nuevas industrias.

Pese a lo dispuesto en la Ley 819 de 2003, en los municipios objeto de estudio no se realiza una estimación del costo fiscal de las exenciones otorgadas para incentivar el asentamiento fiscal o que en su defecto se establezca en el acuerdo municipal la estimación del costo fiscal; lo que demuestra que las entidades territoriales no hacen una evaluación del ingreso renunciado. En consecuencia, la suscitada inobservancia puede tener 
efectos negativos para la estructura tributaria de la entidad territorial, distorsionando de esta manera la gestión, control y recaudo del tributo; propiciando la regresividad del sistema y estimulando la elusión y evasión tributaria; generando beneficios a unos cuantos sectores de la economía e incrementando tarifas a los demás. En consecuencia, en las entidades territoriales objeto de estudio no fue posible establecer el ingreso renunciado, los indicadores de gasto tributario y el sacrificio tributario en el Impuesto de Industria y Comercio en el periodo 2008 al 2017, en consideración a que los entes territoriales objeto de estudio no tienen establecidas políticas que posibiliten determinar el impacto tributario.

Los municipios, según preceptos constitucionales, se consideran como entidades descentralizadas; en efecto, tienen la facultad para administrar y gestionar sus propios recursos; sin embargo, en el periodo objeto de estudio se evidencia que la concesión de beneficios tributarios obedece principalmente a razones políticas, y por lo general benefician a ciertos sectores que inciden en el gobierno de turno.

En los municipios objeto de estudio las exenciones han sido condicionadas a periodos que van desde los 4 a 10 años, no existe una política de evaluación y seguimiento del efecto político, económico y social, producto de las concesiones tributarias. Aunque para los municipios objeto de estudio es evidente que el crecimiento industrial sin duda es más que satisfactorio para el municipio, esto pese a que no existe algún tipo de estudio que explore la incidencia de la medida tributaria en este desarrollo.

Las normas que establecen los requisitos para acceder a los beneficios tributarios son insuficientes y dificultan el control por parte de la Administración tributaria, lo que puede incentivar la evasión y la elusión. Por ejemplo, aspectos como la periodicidad de las exenciones, afectan la liquidación de los tributos, dado que el periodo gravable del impuesto puede no ser necesariamente el mismo que el periodo de la exención.

Para efectos del control y evaluación de los gastos tributarios, se hace necesario que los formularios de presentación de las declaraciones incorporen renglones que permitan captar la información necesaria de acuerdo con el tipo de exención y/o beneficio, de tal forma que la medición del impacto de cada beneficio sea administrado en los sistemas de información para la gestión, análisis y control.

Los requisitos para acceder a los beneficios están dirigidos a grandes industrias; lo que imposibilita a las pequeñas industrias acceder a los beneficios; en este mismo sentido, en algunos casos, la redacción de las normas donde se conceden beneficios son ambiguas, por lo cual se presenta inseguridad jurídica. Así, es posible inferir que las decisiones de inversión no están motivadas por los beneficios tributarios, en el entendido que más del 99\% de las empresas asentadas no se interesaron por acceder a los mismos.

De las industrias que han sido beneficiadas con los tratamientos preferenciales algunas aún se encuentran gozando de los beneficios y las demás continúan asentadas en la jurisdicción después de terminarse el periodo de exención. No obstante, se debe facilitar el diálogo entre las diferentes entidades territoriales, con el fin de promover un desarrollo industrial de largo plazo. 
En las jurisdicciones objeto de estudio se concluye que las exenciones tributarias no constituyen el factor principal en la toma de decisiones para la determinación de la ubicación de las empresas; en efecto, los incentivos tributarios por sí solos no constituyen un factor que promueva una política económica.

En el caso de la exención por asentamiento de nuevas empresas, son más relevantes factores como la infraestructura del Valle de San Nicolás, la zona franca, el túnel de oriente, la cercanía con el Valle de Aburrá; el desarrollo de corredores industriales, la autopista Medellín-Bogotá, y la distancia al aeropuerto José María Córdova.

También es posible concluir que las proyecciones económicas de las entidades territoriales no solo han sido enmarcadas en posibilitar el asentamiento industrial a través de beneficios tributarios, sino por permitir el asentamiento de grandes industrias en lugares estratégicos demarcados en los planes de ordenamiento territorial.

Con respecto a las exenciones que tienen como objetivo la generación de empleo para los residentes de las jurisdicciones, se hace necesario implementar políticas que evalúen la correlación entre la exención y la generación de empleo en la jurisdicción, pues se ha evidenciado que las limitaciones a las exenciones provienen principalmente de la falta de cumplimiento de requisitos.

\section{Referencias}

\section{Libros y capítulos de libro}

A.D Giannini (1957). Instituciones de Derecho tributario (Traducido por Sainz de Bujanda). Madrid: Editorial de Derecho financiero.

Aristizábal Villa, Javier (s.f.). Impuestos Municipales (Primera, Segunda, Tercera y Cuarta Parte, y exenciones).

Buitrago Díaz, Esperanza (Editora) (2016). La crisis de los impuestos locales: el caso del ICA, alumbrado público y estampillas. En: Colombia 2016. Bogotá: Ed: Universidad del Rosario.

Castro, J. et al. (2013). Curso de Derecho Tributario, procedimiento y régimen sancionatorio. Bogotá, Colombia: Universidad Externado de Colombia.

De la Calle, H. y Eastman, J. (1996). En defensa de la descentralización y de la autonomía territorial. Estudios constitucionales. Santafé de Bogotá: Colombo Editores Ltda.

Insignares Gómez, Roberto (2015). El poder tributario: organización y estructura en el Estado colombiano. La obligación tributaria y sus fundamentos constitucionales. Bogotá. 
Jarach, Dino (1969). Curso superior de Derecho tributario. Argentina: Ed, liceo profesional cima, 1 edición.

Ministerio de Hacienda y Crédito Público, Dirección General de Apoyo Fiscal (s.f.). Tributos Distritales y Municipales (Tomo II). Bogotá: Imprenta Nacional de Colombia.

Ospina Cruz, José (2004). Herramientas para la Gestión Tributaria Municipal. Bogotá: Federación Colombiana de Municipios, 154 p.

Parra Ortiz, Harold Ferney (2010). Documento de análisis comparativo del Impuesto de Industria y Comercio en Colombia. Bogotá: Grupo Editorial Nueva Legislación.

Piza Rodríguez, Julio Roberto (Comp.) (2010). Curso de Derecho Tributario, Procedimiento y Régimen Sancionatorio. Bogotá: Universidad Externado de Colombia.

Piza Rodríguez, Julio Roberto (Editor) (2016). Los tributos territoriales en el ordenamiento jurídico colombiano. Un análisis crítico, 2da ed. Bogotá: Universidad Externado de Colombia.

Piza Rodríguez, Julio Roberto; Muñoz, Gabriel e Insignares, Roberto (2015). La obligación tributaria y sus fundamentos constitucionales. Bogotá: Universidad Externado de Colombia.

Quiñones Montealegre, Antonio (2009). Impuesto de industria y comercio: conflictos y propuesta de reforma / Antonio Quiñones Montealegre. Facultad de Jurisprudencia. Bogotá: Editorial universidad del Rosario, 336 p. (Colección Textos de Jurisprudencia).

Rawls, J. (1997). Teoría de la Justicia. México: Fondo de Cultura Económica.

Restrepo Salazar, Juan Camilo (2005). Hacienda Pública. $7^{\text {a }}$ Ed. Bogotá: Universidad Externado de Colombia.

Rodríguez, L. (2013). Derecho administrativo general y colombiano. Bogotá: Editorial Temis S.A.

Stanley, S. (1970). Federal taxation: current cases and comment. The Harvard Law Review.

Velarde Aramayo, María Silvia (1997). Beneficios y minoraciones en Derecho Tributario. Madrid: Marcial Pons. 
Yuones, D. (2007). Curso de Derecho administrativo. Octava edición. Bogotá: Editorial Temis S.A.

\section{Tesis y trabajos de grado}

Cardona B., Juan C. (2019). Beneficios tributarios otorgados por las entidades territoriales en el marco del principio de autonomía territorial. Caso de estudio: exenciones y beneficios fiscales en ICA en los municipios del Valle de San Nicolás; orientado al análisis de los efectos del asentamiento empresarial en los municipios de Rionegro y Guarne en el periodo 2008-2017. Bogotá: Universidad Externado de Colombia.

Alfonso, M. (2015). La descentralización y la autonomía de los municipios en el marco del Estado unitario colombiano. Bogotá: Universidad Militar Nueva Granada.

Bernal Casas; Artunduaga Pineda; Schomberger Tibocha (2005). La titularidad del poder tributario en Colombia. Bogotá: Pontificia Universidad Javeriana.

Calle Aguas, Gabriel Enrique (2012). La ley de reestructuración de pasivos (Ley 550/99) y las implicaciones en la autonomía de las entidades territoriales. Evidencia para el caso departamental. Bogotá: Universidad Externado de Colombia.

Martínez Ardila, Alcy Fernando (2016). Relevancia de la medición del gasto tributario en los impuestos territoriales. Estudio de caso: Impuesto de Industria y Comercio en Cota Cundinamarca. Bogotá: Universidad Externado de Colombia.

Perdomo, G. (2018). Exenciones y beneficios tributarios del orden territorial. Expresión de la autonomía conferida a los entes territoriales que vulnera el principio de reserva legal en materia tributaria. Bogotá: Universidad Externado de Colombia.

Robledo S., Paula (2010). La autonomía municipal en Colombia Bogotá: Universidad Externado de Colombia.

Rodríguez Cruz, J. P. (julio - diciembre, 2014). El principio de la autonomía territorial de los municipios y departamentos en Colombia, análisis y perspectivas desde la jurisprudencia de la Corte Constitucional 1992-2012. Summa Iuris, 2(2), 275-302.

Ruiz, Carolina y Zuluaga, Sebastián (2018). Incidencia del asentamiento de empresas en el Municipio de Guarne sobre la estructura tributaria. Rionegro, Antioquia: Universidad Católica de Oriente. 
Soto, D. (s.f.). La descentralización en Colombia: Centralismo o Autonomía. Bogotá: Universidad Externado de Colombia.

Uribe U., Rafael (2005). Módulo Hacienda Pública. Especialización en Gestión Tributaria. Medellín: Universidad de Antioquia. Documento inédito.

Vargas, R. (2009). Exenciones tributarias por los impuestos predial, de industria y comercio y de avisos y tableros, y su impacto en el nivel de recaudo y asentamiento empresarial de los municipios de Guarne, Marinilla, El Carmen de Viboral, Rionegro y La Ceja (2002-2007). (p.113)

\section{Documentos institucionales}

Bautista, Jairo (2015). Los beneficios tributarios en el impuesto de renta: Análisis de sus determinantes técnicos y su impacto fiscal. Red por la Justicia tributaria. Recuperado de: http://justiciatributaria.co/wpcontent/uploads/2014/10/DOCUMENTO-FINAL-ANALISIS-BENEFICIOS-TRIBUTARIOS-IMPUESTO-DE-RENTA.pdf

Cámara de Comercio del Oriente Antioqueño (2017). Concepto económico 2017. Recuperado de: https://www.ccoa.org.co/Portals/0/Concepto-economico-del-oriente-antioqueno-2017_1.pdf

Jiménez, J.; Podesta, A. (2009). Inversión, incentivos fiscales y gastos tributarios en América Latina. Santiago de Chile. Recuperado de http://andi.com.co/czf/Documents/Documentos\%20de\%20Interes/Microsoft $\% 20$ Word $\% 20 \% 20$ Inversi $\%$ C3\%B3n,\%20Incentivos $\% 20$ fiscales $\% 20$ en $\% 20$ America $\% 20$ Latina $\% 20$ Cepal\%20Documento.pdf

Pardo, Álvaro (2016). Radiografía de los beneficios onerosos en el Estatuto Tributario. Colombia punto medio. Recuperado de: http://www.colombiapuntomedio.com/ Portals/0/Archivos2016/Beneficios_tributarios_y_costo_fiscal2.pdf

Simonit, S. (10 de 12 de 2013). CEPAL. Recuperado de www.cepal.org/de/noticias/paginas/0/9200/3simonit.pdf

Centro de Pensamiento en Estrategias Competitivas (Cepec) (2012). Tres Valles: el territorio de la economía. Una estrategia de ordenamiento económico-territorial para los valles de Aburrá, Occidente Cercano y San Nicolás en Antioquia., Universidad del Rosario; Dirección del Proyecto: Saúl Pineda Hoyos. Bogotá: Editorial Universidad del Rosario, $412 \mathrm{p}$. 


\section{Otros}

Jaramillo A., Ana M. (2007). El oriente Antioqueño. Recuperado de: https://biblio.flacsoandes.edu.ec/catalog/resGet.php?resId=19314.

Herrera, M. (2018). Capacitación industria y comercio régimen común, Guarne, Antioquia.

Municipio de Guarne (2017). Expediente Municipal aproximación al mercado laboral-Municipio de Guarne a octubre de 2017. Documento de seguimiento y evaluación al plan básico de ordenamiento territorial y estadísticas municipales.

Penagos, G. (2003). La descentralización territorial en el Estado unitario. Universitas. Recuperado de http://www.javeriana.edu.co/jurídicas/pub_rev/documents/9-24. pdf

\section{Normatividad}

Congreso de la República. Ley 14 (06 de julio, 1983). Por la cual se fortalecen los fiscos de las entidades territoriales y se dictan otras disposiciones.

Presidencia de la República de Colombia. Decreto 1333 de 1986. Por el cual se expide el Código de Régimen Municipal.

Congreso de la República de Colombia. Ley 14 de 1983. Por la cual se fortalecen los fiscos de las entidades territoriales y se dictan otras disposiciones.

Congreso de la República de Colombia. Ley 75 de 1986. Por la cual se expiden normas en materia tributaria de catastro de fortalecimiento y democratización del mercado de capitales se conceden unas facultades extraordinarias y se dictan otras disposiciones.

Congreso de la República de Colombia. Ley 84 de 1915. Por la cual se reforman y adicionan las leyes 4 y 97 de 1913 .

Congreso de la República de Colombia. Ley 97 de 1913. Por la cual se da autorizaciones especiales a ciertos concejos municipales.

Congreso de la República de Colombia. Ley 1819 (29 de diciembre, 2016). Por medio de la cual se adopta una reforma tributaria estructural, se fortalecen los mecanismos para la lucha contra la evasión y elusión fiscal, y se dictan otras disposiciones. 
Congreso de la República de Colombia. Ley 1819 (29 de diciembre, 2016). Por medio de la cual se adopta una reforma tributaria estructural, se fortalecen los mecanismos para la lucha contra la evasión y elusión fiscal, y se dictan otras disposiciones.

Municipio de Guarne (2008). Acuerdo 059 (22 de diciembre de 2008). Por el cual se adopta el estatuto tributario y de bienes, el procedimiento tributario y el régimen sancionatorio tributario para el Municipio de Guarne, Antioquia.

Municipio de Guarne (2013). Acuerdo 004 (28 de agosto de 2013). Por medio del cual se expide la normativa sustantiva y procedimental aplicable a los ingresos tributarios en el Municipio de Guarne.

Municipio de Guarne (2016). Acuerdo 04 (31 de octubre de 2016). Por medio del cual se adopta el Plan de Desarrollo Municipal 2016-2019 “Tus ideas nos inspiran, construcción colectiva de futuro".

Municipio de Guarne (2016). Acuerdo 07 (17 de mayo de 2016). Por medio del cual se adopta el estatuto tributario del Municipio de Guarne Antioquia.

Municipio de Guarne (2017). Expediente Municipal aproximación al mercado laboral-Municipio de Guarne a octubre de 2017. Documento de seguimiento y evaluación al plan básico de ordenamiento territorial y estadísticas municipales.

Municipio de Rionegro (2005). Acuerdo 029. Por el cual se adopta el Estatuto Tributario y de bienes, el procedimiento tributario y el régimen sancionatorio tributario para el Municipio de Rionegro, Antioquia.

Municipio de Rionegro (2012). Acuerdo 063. Por medio del cual se expide la normativa sustantiva y procedimental aplicable a los ingresos tributarios en el Municipio de Rionegro, Antioquia.

Municipio de Rionegro (2014). Acuerdo 009. Por medio del cual se adopta el estatuto tributario del Municipio de Rionegro, Antioquia.

Secretaría del Senado de la República de Colombia. Constitución Política de Colombia. 


\section{Jurisprudencia}

\section{Corte Constitucional}

Corte Constitucional, Sala Plena. Sentencia C- 183 de 1998. M.P.: Eduardo Cifuentes Muñoz.

Corte Constitucional. Sentencia C-1107 de 2001. M.P.: Jaime Araujo Rentería.

Corte Constitucional. Sentencia C-799 de 1999. M.P.: José Gregorio Hernández Galindo.

Corte Constitucional. Sentencia C-397 de 2011. M.P.: Jorge Ignacio Pretelt Chaljub.

Corte Constitucional. Sentencia C-517 de 1992. M.P.: Ciro Angarita Barón.

Corte Constitucional. Sentencia C-335 de 1996. M.P.: Jorge Arango Mejía.

Corte Constitucional. Sentencia C-748 de 2009. M.P.: Rodrigo Escobar Gil.

Corte Constitucional. Sentencia C-537 de 1995. M.P.: Hernando Herrera Vergara.

Corte Constitucional. Sentencia C-740 de 1999. M.P.: Álvaro Tafur Galvis.

Corte Constitucional. Sentencia C-506 de 1995. M.P.: Carlos Gaviria Díaz.

Corte Constitucional. Sentencia C-205 de 1995. M.P.: Juan Manuel Charry Urueña.

Corte Constitucional. Sentencia C-517 de 2007. M.P.: Rodrigo Escobar Gil.

Corte Constitucional. Sentencia C-084 de 1995. M.P.: Alejandro Martínez Caballero.

Corte Constitucional. Sentencia C-891 de 2012. M.P.: Jorge Ignacio Pretelt Chaljub.

Corte Constitucional. Sentencia C-413 de 1996. M.P.: José Gregorio Hernández Galindo.

Corte Constitucional. Sentencia C-1097 de 2001. M.P.: Jaime Araújo Rentería.

Corte Constitucional. Sentencia C-227 de 2002. M.P.: Jaime Córdoba Triviño.

Corte Constitucional. Sentencia C-504 de 2002. M.P.: Jaime Araújo Rentería. 
Corte Constitucional. Sentencia C-1043 de 2003. M.P.: Jaime Córdoba Triviño.

Corte Constitucional. Sentencia C-540 de 2005. M.P.: Humberto Antonio Sierra Porto.

Corte Constitucional. Sentencia C-517 de 2007. M.P.: Rodrigo Escobar Gil.

Consejo de Estado

Consejo de Estado. Expediente 16949 de 2011. Sección Cuarta. C.P.: Hugo Fernando Bastidas Bárcenas. 